Portland State University

PDXScholar

Civil and Environmental Engineering

Undergraduate Honors Theses

$6-21-2018$

\title{
Precipitation Impacts on Groundwater Levels in the Ephemeral Holgate Lake: A MODFLOW Inquiry
}

Amory Cervarich

Portland State University

Follow this and additional works at: https://pdxscholar.library.pdx.edu/cengin_honorstheses

Part of the Civil and Environmental Engineering Commons

Let us know how access to this document benefits you.

\section{Recommended Citation}

Cervarich, Amory, "Precipitation Impacts on Groundwater Levels in the Ephemeral Holgate Lake: A MODFLOW Inquiry" (2018). Civil and Environmental Engineering Undergraduate Honors Theses. 11. https://doi.org/10.15760/honors.639

This Thesis is brought to you for free and open access. It has been accepted for inclusion in Civil and Environmental Engineering Undergraduate Honors Theses by an authorized administrator of PDXScholar. Please contact us if we can make this document more accessible: pdxscholar@pdx.edu. 
Precipitation Impacts on Groundwater Levels in the Ephemeral Holgate Lake:

A MODFLOW Inquiry

by

Amory Cervarich

A thesis submitted in partial fulfillment

of the requirement for the degree of

\title{
BACHELOR OF SCIENCE WITH HONORS
}

IN

CIVIL AND ENVIRONMENTAL ENGINEERING

\author{
Thesis Advisor: \\ GR Johnson, PhD
}

Portland State University

(C)2018 


\section{ACKNOWLEDGMENTS}

Dr. Johnson, for generously sharing her brain space and lab space. And for pulling me out of rabbit holes.

Linley Mescher, for all the MODFLOW collaboration.

PP and JMV, for the late night dinners and endless support.

And to RC, for keeping the lights on. 


\begin{abstract}
Holgate Lake, an ephemeral lake located in southeast Portland, has a history of flooding and inundating residential areas. The appearance of the lake is hypothesized to be a function of precipitation-driven changes in groundwater levels. A model was developed using MODFLOW-NWT, a U.S. Geological Survey (USGS) modular hydrologic program, to analyze parameters contributing to the appearance of the lake. The model was most sensitive to changes in aquifer properties including hydraulic conductivity and storativity. The model displayed low sensitivity to changes in precipitation, evapotranspiration, and conductance of surface waters. Results from the analysis contribute to a better understanding of the surface-groundwater system, and could be used to assess flooding risks in the Holgate Lake area with additional model calibration.
\end{abstract}




\section{TABLE OF CONTENTS}

1 INTRODUCTION

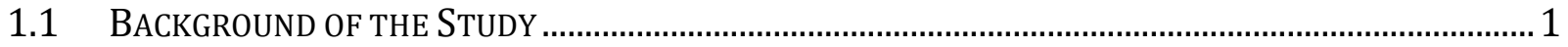

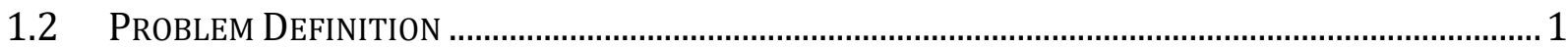

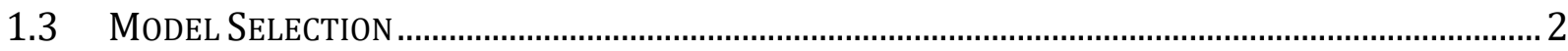

1.4 STUDY AREA ......................................................................................................................

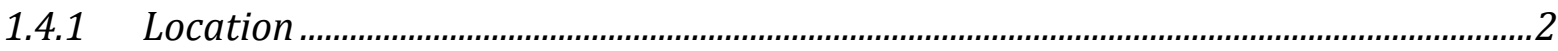

1.4.2 Climate

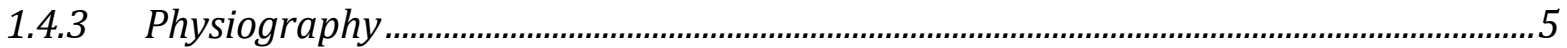

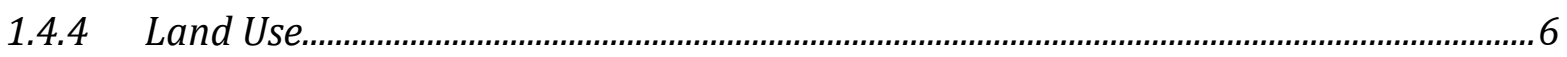

1.4.5 Geology

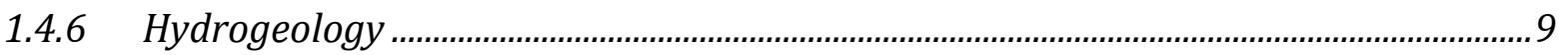

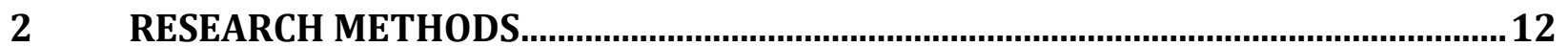

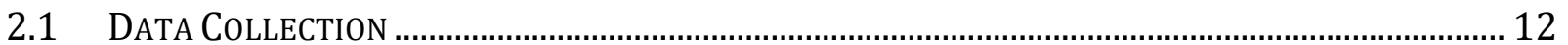

2.2 DATA PROCESSING......................................................................................................... 12

2.2.1 Precipitation ..........................................................................................................13

2.2.2 Potential Evapotranspiration Estimation..................................................................... 13

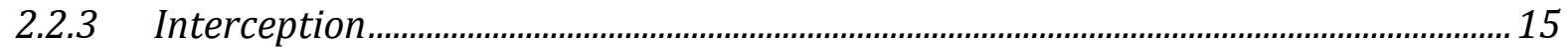

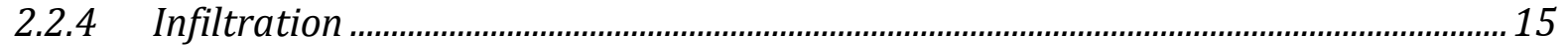

2.3 CONCEPTUAL MODEL ............................................................................................................ 16

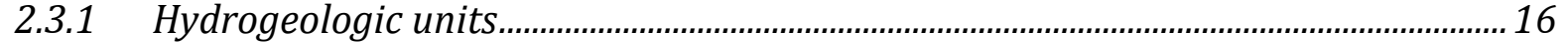

2.3.2 Surface Water and Flow Directions .............................................................................16

2.3.3 External and internal model physical boundaries...........................................................16

2.4 NUMERICAL MODEL ........................................................................................................... 17

2.4.1 General Concepts........................................................................................................1

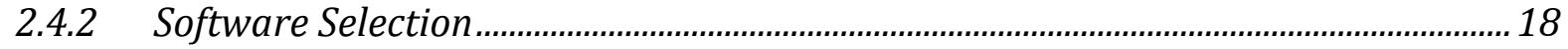

2.4.3 Grid design ............................................................................................................19

2.4.4 Structural Model ................................................................................................... 19

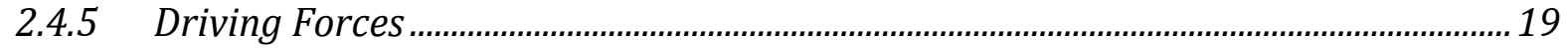


2.4.6 System Parameterization ………….............................................................................20

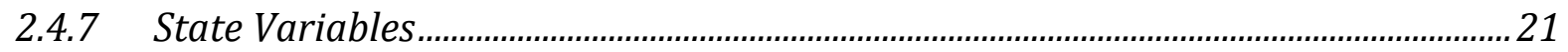

2.4.8 Time Discretization and Initial Conditions of Transient Model....................................22

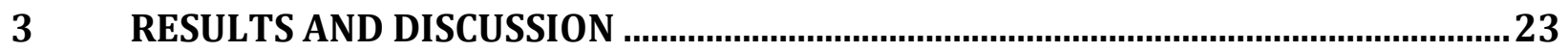

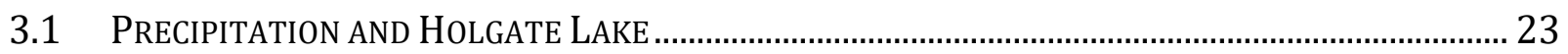

3.2 ERror AsSESSMENT AND GroundWATER HEADS........................................................................ 24

3.3 SENSITIVITY ANALYSIS......................................................................................................... 29

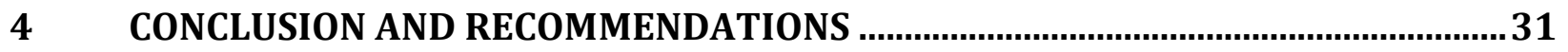

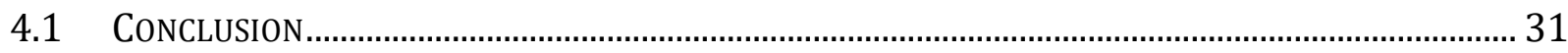

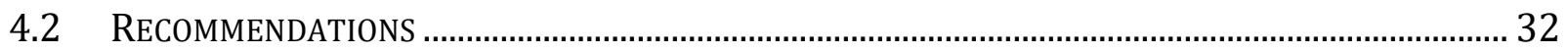

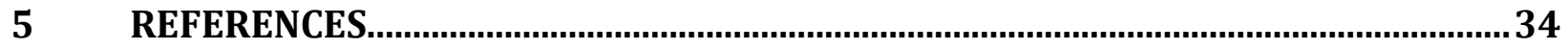




\section{LIST OF TABLES}

Table 1: Conceptual model hydrogeologic units............................................................................ 16

Table 2: Hydraulic Conductivity and Storage Parameters ............................................................ 21

\section{LIST OF FIGURES}

Figure 1: Meridian and base line for the US Government's Rectangular Survey System

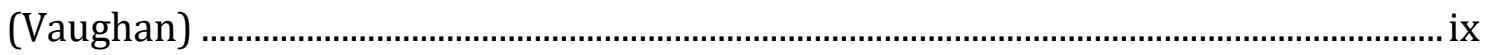

Figure 2: Location system and well identifier explanation (Snyder 2008) .................................

Figure 3: Holgate Lake appearance from March 2006 (Williams et al. 2010) ............................. 1

Figure 4: Holgate Lake location at the western foothills of Powell Butte (The National Map

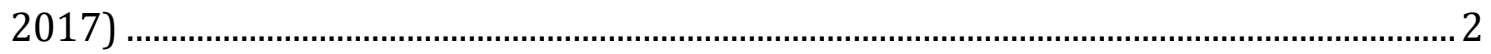

Figure 5: Water level elevation (1999-2004) of Holgate Lake, in wells in proximity to Holgate

Lake, and precipitation at Holgate rain gage........................................................................... 4

Figure 6: Model domain as delineated by the rectangular survey system. Section numbers are indicated in red in the middle of each section .............................................................

Figure 7: Land use within the Johnson Creek Watershed with the study area indicated by the black rectangle (Johnson Creek Watershed Characterization 2005) ............................. 6

Figure 8: Willamette Basin and its five subbasins (Conlon et al. 2005) ......................................... 7

Figure 10: Geology of Portland and adjacent areas (Trimble 1963) .............................................. 8

Figure 11: Relationship between the geology and hydrogeology in the Portland Basin

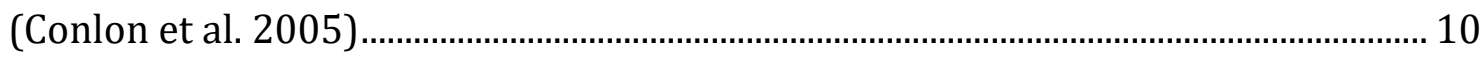

Figure 12: Precipitation from Holgate rain gage and daily temperature from the Portland Weather Forecast Office .................................................................................................... 13

Figure 13: Potential evapotranspiration calculated using the Hargreaves Method ................ 15

Figure 14: Digital Elevation Model (DEM) of the study area with elevation in feet ................ 19

Figure 15: Horizontal hydraulic conductivity (feet/day) in the Unconsolidated Sedimentary

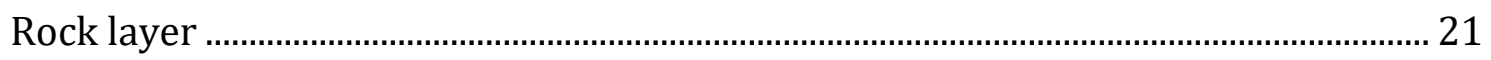

Figure 16: Model domain and wells used for initial conditions (NWIS Site Information for

Oregon: Site Inventory) .................................................................................................. 22

Figure 17: Initial head distributions, June 14, 1999................................................................... 22 
Figure 18: Relation between net annual rise in groundwater level at well 01S/02E-14ABC and cumulative WY precipitation at the Holgate rain gage from WY 1999 to WY 2006

Figure 19: Relation between net annual rise in groundwater level at well 01S/02E-14ABC and cumulative WY precipitation at the Holgate rain gage from WY 1999 to WY 2011 23

Figure 20: Residuals vs. simulated order for well 01S/02E-14ABC and 01S/02E-14BAD ... 24

Figure 21: Simulated vs. observed heads at well 01S/02E-14ABC and well 01S/02E-14BAD for the 318-day model run ............................................................................................ 25

Figure 22: Simulated vs. observed heads at well 01S/02E-14ABC and well 01S/02E-14BAD for day 1 to day 150 .................................................................................................... 26

Figure 23: Simulated vs. observed heads at well 01S/02E-14ABC and well 01S/02E-14BAD for day 150 to day 318 .................................................................................................. 26

Figure 24: Simulated vs. observed heads at well 01S/02E-14ABC and well 01S/02E-14BAD for each modeled month presented with cumulative monthly precipition ................ 26

Figure 25: Monthly regression analysis results of simulated vs. observed heads at well 01S/02E-14ABC and well 01S/02E-14BAD, June 1999 to September 1999 ............ 27

Figure 26: Monthly regression analysis results of simulated vs. observed heads at well 01S/02E-14ABC and well 01S/02E-14BAD, October 1999 to December 1999....... 28

Figure 27: Monthly regression analysis results of simulated vs. observed heads at well 01S/02E-14ABC and well 01S/02E-14BAD, January 2000 to April 2000.................. 28

Figure 28: Sensitivity analysis of model input parameters .......................................................... 29

Figure 29: Sensitivity of aquifer parameters.................................................................................. 30

Figure 30: Sensitivity of hydrologic parameters …………......................................................... 30

Figure 31: Sensitivity of UZF model parameters .......................................................................... 30

Figure 32: Sensitivity of UZF parameters with graph scaled for comparison to aquifer

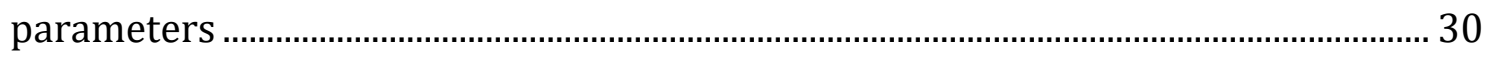

Figure 33: Observed and simulated heads at well 01S/02E-14BAD compared to lakebed and flood levels. 


\section{CONVERSION FACTORS}

This report uses the North American Vertical Datum of 1988 (NAVD 88) as its datum. For elevation data collected in NGVD 29, the following conversion was utilized:

$$
N A V D 88=N G V D 29+3.5 f t
$$

The conversion is accurate to +/- 0.5 feet (Snyder and Haynes 2010). 


\section{WELL LOCATION SYSTEM}

The Rectangular Survey System for the subdivision of public lands was used in this study to locate wells. In Oregon, the meridian and base line intersect in Portland's West Hills at the Willamette Stone (Figure 1). The principle survey meridian is the Willamette Meridian, which runs north-south from the Puget Sound to California. The base line is the Willamette Base Line, which runs east-west and is positioned south of the Columbia River and north of Mount Hood. The numbers and letters indicate the township, range, section, and location within the section by quarter section (160 acres), quarter-quarter section (40 acres), quarter-quarter-quarter section (10 acres), and quarter-quarter-quarter-quarter section (2.5 acres). Additional identification numbers follow the final section letter to ensure uniqueness (Figure 2).

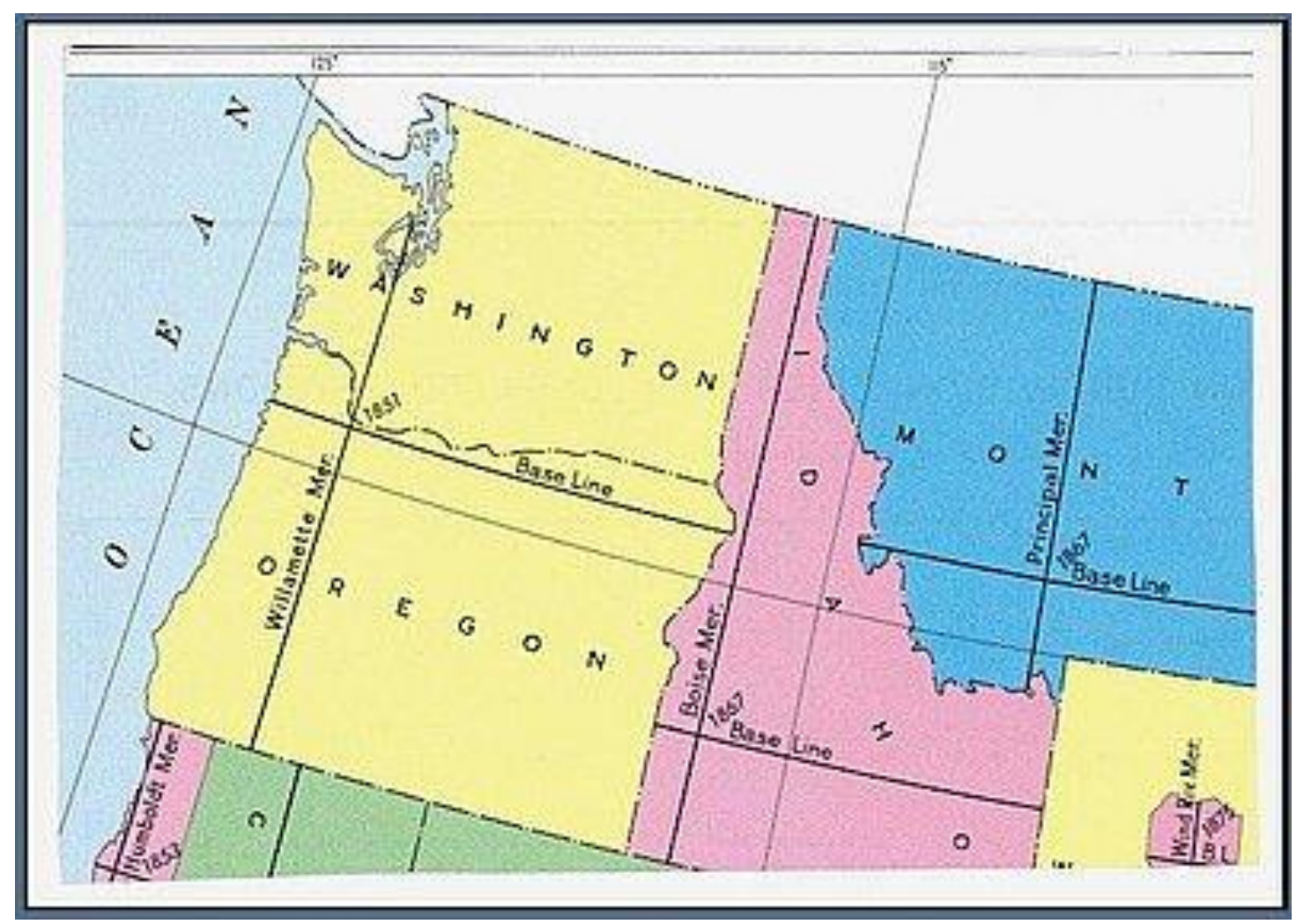

Figure 1: Meridian and base line for the US Government's Rectangular Survey System (Vaughan) 


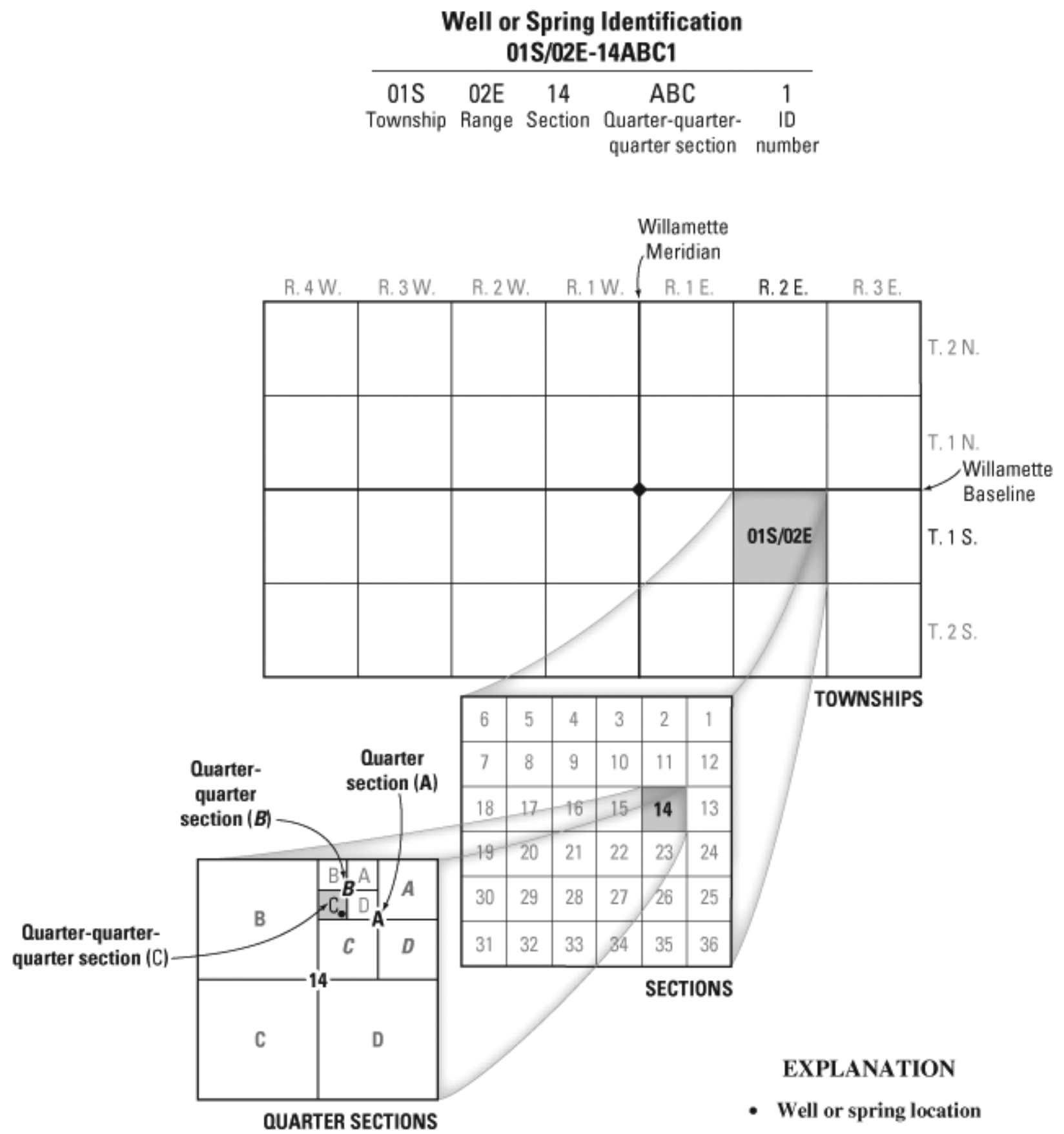

Figure 2: Location system and well identifier explanation (Snyder 2008) 


\section{INTRODUCTION}

\subsection{Background of the Study}

This study aimed to model the relationship between precipitation and the appearance of Holgate Lake. To model the interactions in the Portland Basin at Holgate Lake, this study used MODFLOW-NWT coupled with ModelMuse, a graphical user interface supporting simple implementation of user-specified components qualifying subsurface hydrodynamics. For this study, the model incorporated the Unsaturated-Zone Flow (UZF) and Drain (DRN) packages to explore surface-groundwater interactions. The model was run under transient conditions over a period of 318 days from June 14, 1999 to April 26, 2000.

\subsection{Problem Definition}

Holgate Lake is an ephemeral lake located in southeast Portland. Since record keeping began in the 1940s, the lake has appeared intermittently and flooded surrounding residential areas. The water-surface elevation of the lake is consistent with groundwater levels recorded in a near-by well. Fluctuations in groundwater levels caused by seasonal precipitation are hypothesized to cause flooding in the area (Lee and Snyder 2009). MODFLOW-NWT, a groundwater modeling program, was used to analyze parameters contributing to the intermittent appearance of the lake.

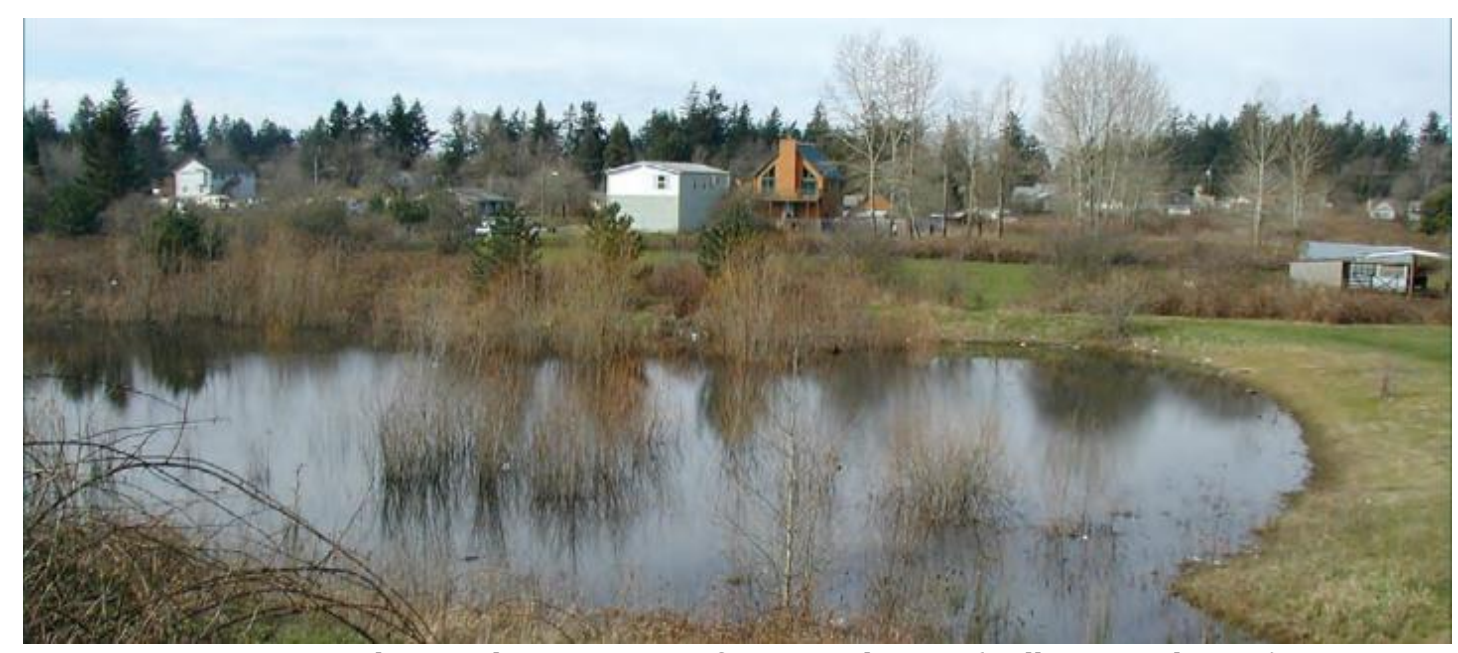

Figure 3: Holgate Lake appearance from March 2006 (Williams et al. 2010) 


\subsection{Model Selection}

This study employed MODFLOW-NWT to model surface-subsurface interactions. MODFLOW-NWT is a groundwater-flow model developed by the U.S. Geological Survey in 2011. It provides a Newton formulation for MODFLOW-2005. The Newton method is a numerical method used to solve nonlinear differential equations. MODFLOW-NWT was developed to solve the groundwater-flow equation for unconfined aquifer systems with drying and rewetting irregularities (Niswonger et al. 2011).

\subsection{Study Area}

\subsubsection{Location}

Holgate Lake is located in southeast Portland in the Powellhurst-Gilbert neighborhood near $136^{\text {th }}$ Avenue and Holgate Boulevard at latitude $45^{\circ} 29^{\prime} 19^{\prime \prime}$ and longitude $122^{\circ} 31^{\prime} 37^{\prime \prime}$ (Figure 4). It is a small topographic depression located at the west end of Powell Butte in the Johnson Creek floodplain. It has caused neighborhood flooding numerous times over the past several decades (Lee and Snyder 2009). Based on current street design and area development, flooding occurs when the lake level exceeds approximately 194.5 feet.

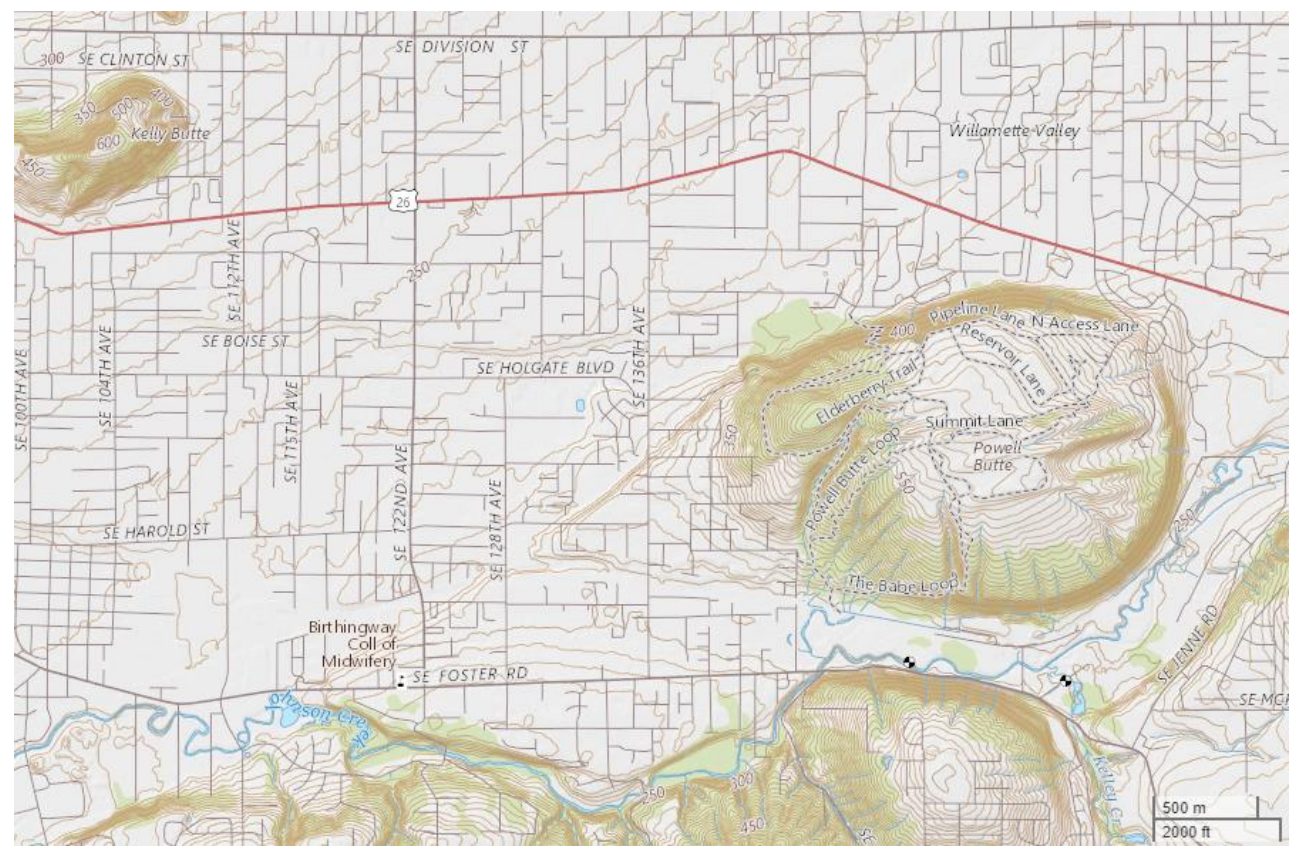

Figure 4: Holgate Lake location at the western foothills of Powell Butte (The National Map 2017) 
Flooding was first recorded in the area in March 1949, though residents observed flooding in the area in 1943. Using photographic inference, the elevation of the lake was estimated to be between 194 and 199 feet. The Gresham Outlook attributed the appearance of the lake to seepage from surrounding slopes, and reported that water levels rose 6 feet over a one week timespan (Gresham Outlook 1949).

Flooding was reported again in 1969. The water-surface elevation was estimated at 203 feet and covered an area of approximately 50 acres. The flooding was attributed to rising water table levels and above average annual precipitation (Gresham Outlook 1969).

In February 1996, Holgate Lake made another appearance. City of Portland responded by pumping $5 \mathrm{Mgal} / \mathrm{d}$ over the following month from the lake. The pumping was not successful in lowering the lake level. The elevation of the lake was estimated at 199 feet based off of aerial imagery (Lee and Snyder 2009).

In February 1999, the USGS began monitoring lake surface elevation levels with a waterlevel recorder. The recorder operated until June 2004. Groundwater level monitoring near Holgate Lake began in October 1998 at well 01S/02E-14ABC. The well is located near SE $133^{\text {rd }}$ Avenue and Raymond Street, which is approximately 0.2 miles from Holgate Lake. In June 1999, a hand-driven piezometer (01S/02E-14BAD) was installed in the lakebed. Observations were collected periodically from June 1999 to March 2001. An additional well site (01S/02E-14BAA) was installed in 2000 in close proximity to the lakebed as the piezometer in the lakebed was often inaccessible. Observations were recorded at this well site until March 2018. The well observations have allowed the pattern of the lake to be qualified (Figure 5). The total monthly precipitation from Holgate rain gage was graphed relative to groundwater levels from the three wells in proximity to the lake and relative to the surface-water level of the lake. The lake typically appears in early winter and returns to a dry lakebed by midsummer. Holgate Lake surface-water level follows a similar trend to groundwater levels from the three local wells. 


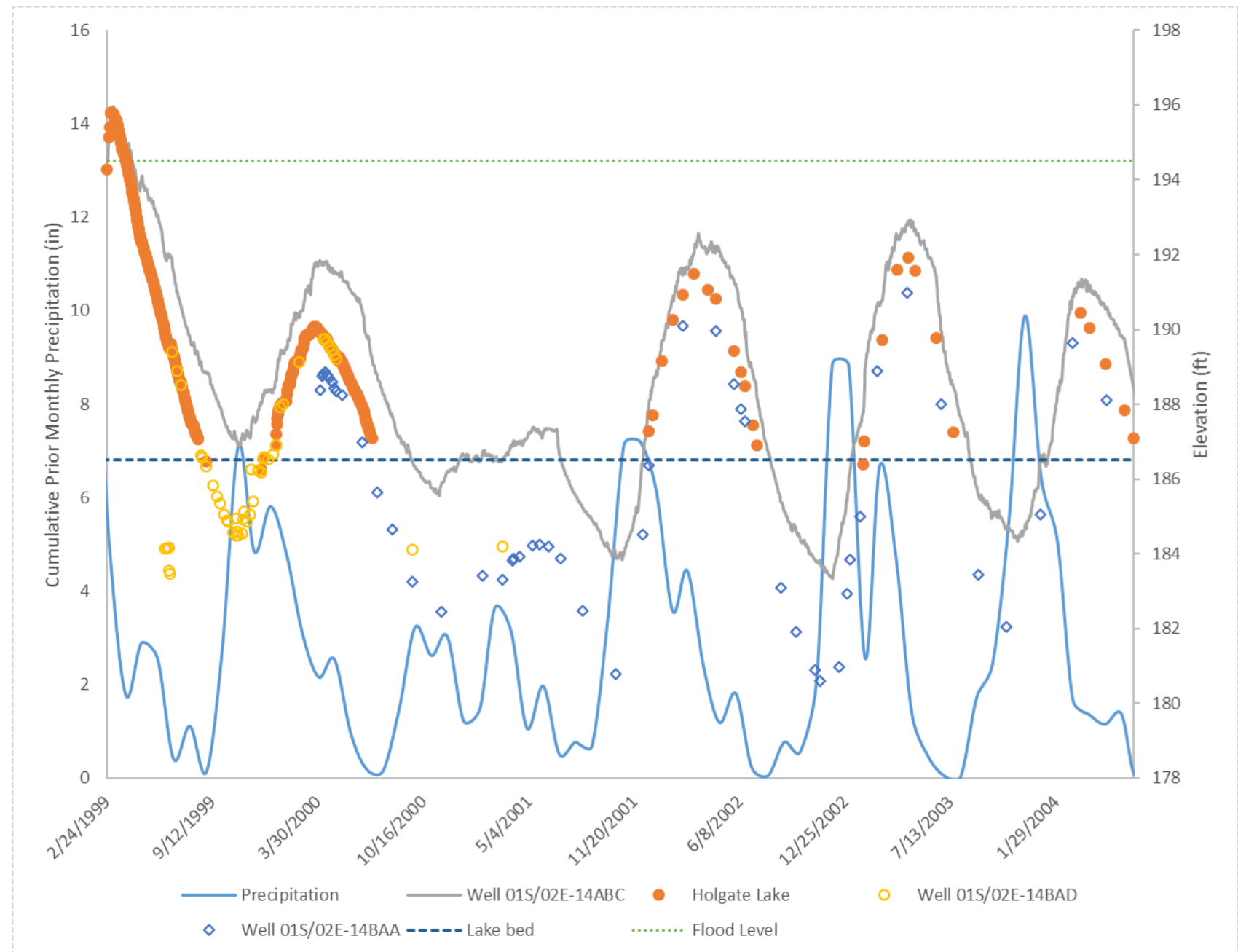

Figure 5: Water level elevation (1999-2004) of Holgate Lake, in wells in proximity to Holgate Lake, and precipitation at Holgate rain gage

\subsubsection{Climate}

The study area has a temperate marine climate, and is characterized by mild, wet winters and warm, dry summers. The mean annual minimum and maximum air temperatures over the basin area are $6.17^{\circ} \mathrm{C}$ and $16.89^{\circ} \mathrm{C}$, respectively. Approximately 70 percent of the annual precipitation occurs between November and March, with less than 10 percent falling between July and September (Lee and Snyder 2009). Average annual precipitation over the area is 48.7 inches (USGS StreamStats). Evapotranspiration is estimated to range from 15 to 16 inches per year in the aquifer system (Woodward et al. 1998). 


\subsubsection{Physiography}

The study area is a topographic depression located at the western foothill of Powell Butte with a surface elevation of approximately 193.5 feet. A 1.1-mile section of Johnson Creek with an average elevation of 234 feet borders the southeastern edge of the study area. Kelly Butte delineates the northwestern edge of the study area with an elevation of 586 feet. Powell Butte borders the eastern edge of the modeled area with an elevation of 620 feet. The model boundaries cover an area of approximately 6 square miles delineated by sections 10 through 15 in Township 1 south, Range 2 east (01S/02E) (Figure 6).

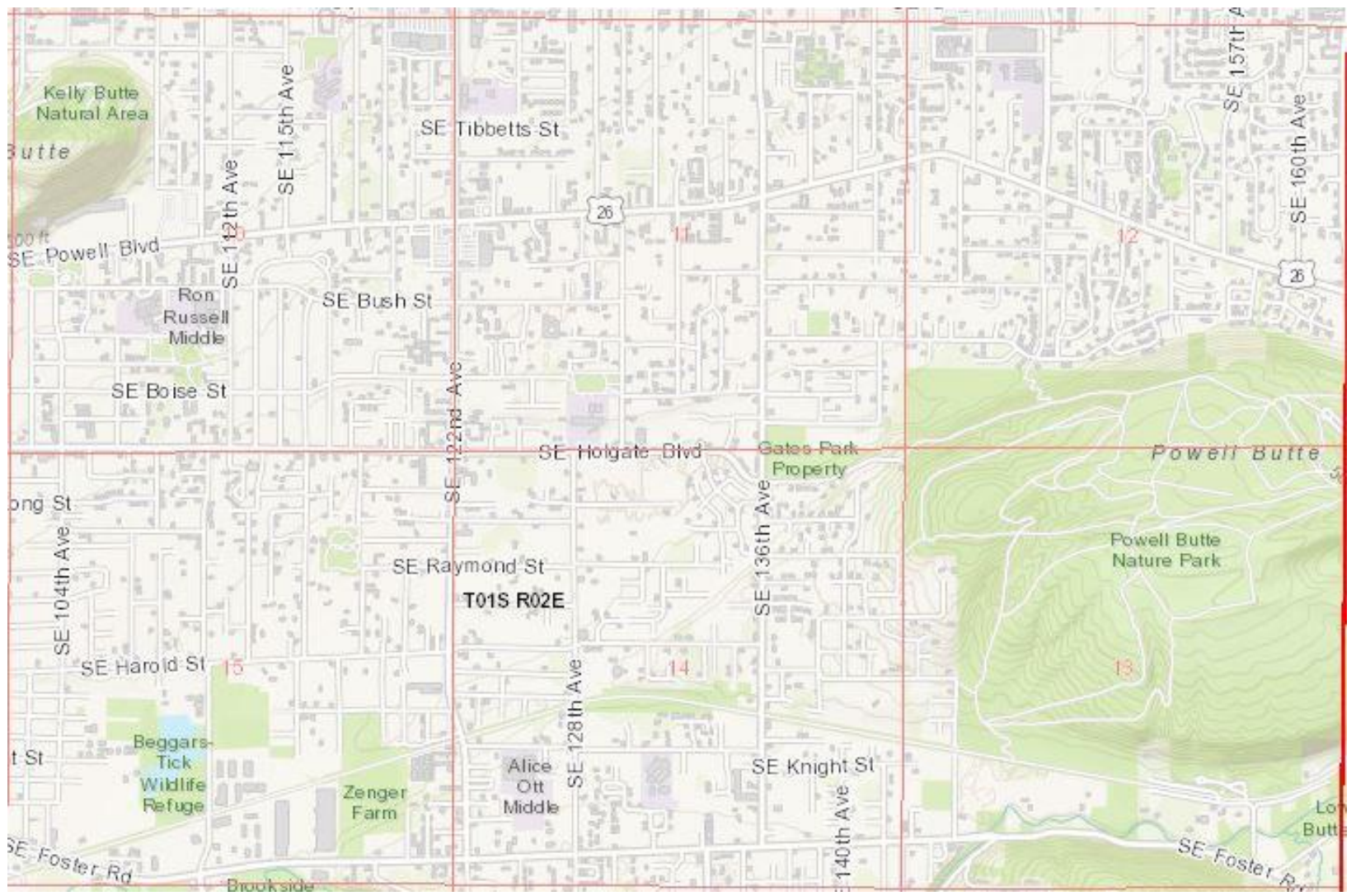

Figure 6: Model domain as delineated by the rectangular survey system. Section numbers are indicated in red in the middle of each section 


\subsubsection{Land Use}

The study area is primarily comprised of single dwelling residential units with a small presence of industrial zones, commercial zones, and open space (Figure 7). Using the National Land Cover Database classifications, the study area was estimated to be 47 percent medium intensity development (50-79\% impervious area), 36 percent low intensity development (20-49\% impervious area), six percent high intensity development (80-100\% impervious area), and four percent open space (less than 20 percent impervious area). In total, approximately 48.6 percent of the study area was estimated as impervious surface area, 16.8 percent as forested, and 34.6 percent as grass-covered (USGS StreamStats).

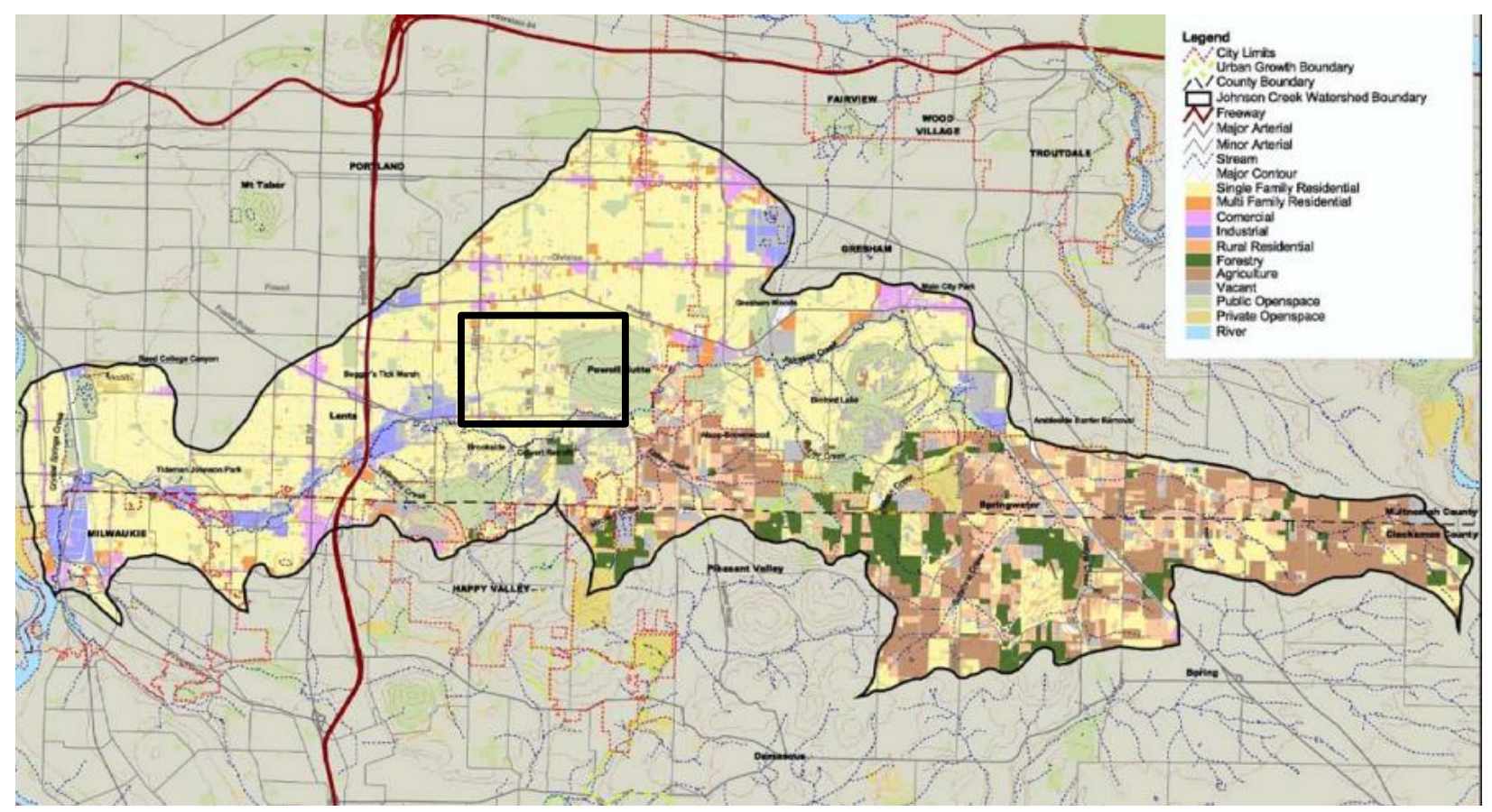

Figure 7: Land use within the Johnson Creek Watershed with the study area indicated by the black rectangle (Johnson Creek Watershed Characterization 2005) 


\subsubsection{Geology}

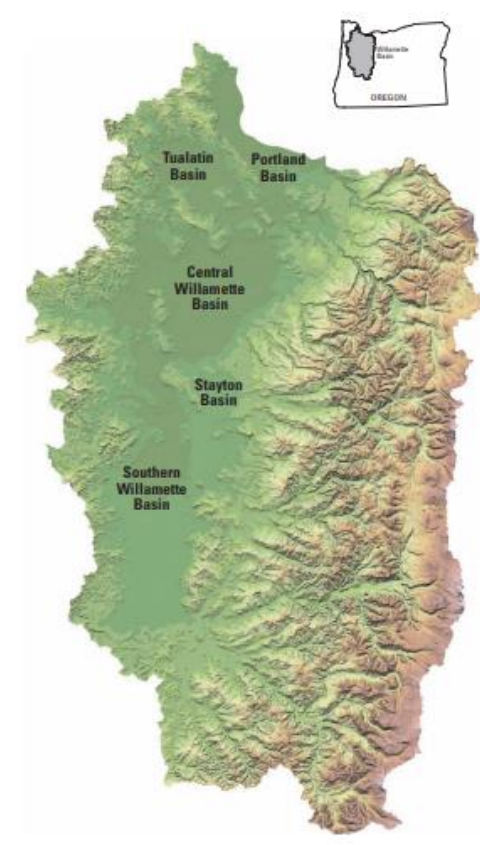

Figure 8: Willamette Basin and its five subbasins (Conlon et al. 2005)
The study area is located in the Portland Basin, which is part of the Willamette Basin (Figure 8). This report adapts the geology of the Portland Basin as studied by Swanson et al. (1993). The Willamette Basin is subdivided into five sedimentary subbasins with the Portland Basin located at its northern end. The Portland Basin is approximately 1300 square miles and extends from northwestern Oregon into southwestern Washington (Swanson et al. 1993). It is delineated by the Tualatin Mountains, colloquially known as the Portland Hills, on the west and the Cascade Range to the north, south, and east. The basin is on average 20 miles wide and 45 miles in length. It is composed of continental, sedimentary rocks most likely of the late Miocene, Pliocene, and Pleistocene age (Figure 9). The west, north, and east boundaries of the basin are formed by outcroppings of older Eocene to Miocene volcanic and sedimentary rocks that also underlie the basin. Consolidated and unconsolidated continental sedimentary rocks fill the basin, and define aquifer units within the basin. The basin is defined by distinct geological units: older rocks, the Sandy River Mudstone and Troutdale Formation, the Cascade Range volcanics and Boring Lava, and the Late Pliocene to Holocene sediments (Swanson et al. 1993). 


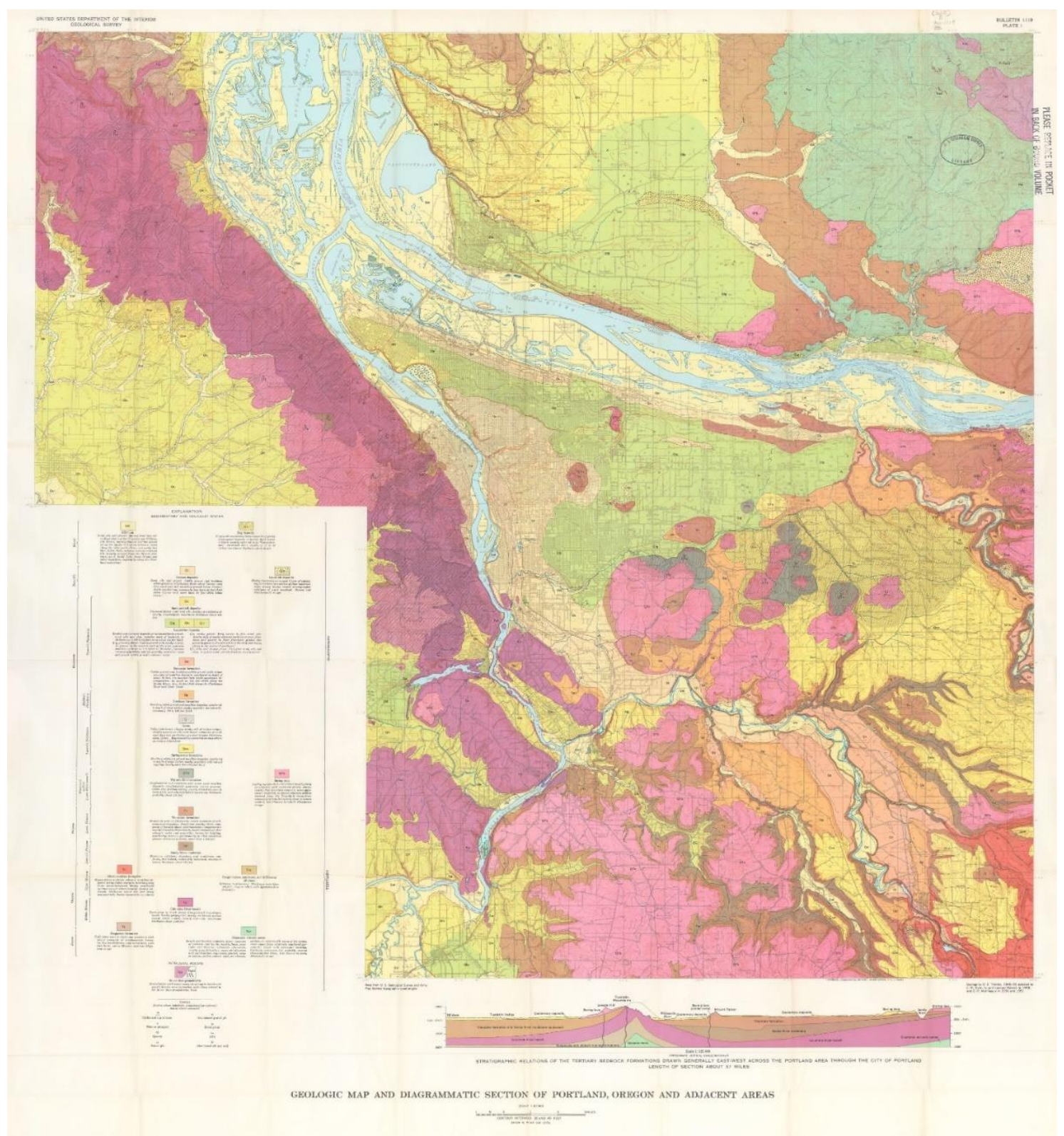

Figure 9: Geology of Portland and adjacent areas (Trimble 1963)

\subsubsection{Older Rocks}

Older rocks underlie the Portland Basin and form outcroppings at the basin's west, north, and east extents. The older rocks are primarily composed of the Skamania Volcanics and the Columbia River Basalt Group. The older rocks form an extensive bedrock unit that generally has poor water-bearing characteristics. The thickness of this group is estimated to range from 0 to over 700 feet, with a maximum thickness of approximately 1000 feet. 


\subsubsection{Sandy River Mudstone and Troutdale Formation}

The Sandy River Mudstone and the Troutdale Formation comprise the oldest sediments found in the Portland Basin. Sandy River Mudstone is composed of mudstone, siltstone, sand and claystone. The formation is generally located immediately above the older rocks of the basin, and extends to thicknesses up to 1400 feet. The Troutdale Formation is made of quartzite conglomerate and glassy sandstone. The formation is typically found above the Sandy River Mudstone, and it is considered a significant water-bearing unit in the Portland Basin. The Troutdale Formation varies in thickness from 75 feet to 400 feet.

\subsubsection{Cascade Range Volcanics and Boring Lava}

The Cascade Range volcanics and Boring Lava form boundary conditions for the Portland Basin and create local features, including the Portland Hills. The Cascade Range volcanics are upwards of 3000 feet thick. The Boring Lava unit is upwards of 400 feet thick.

\subsubsection{Late Pliocene to Holocene Sediments}

The majority of the Portland Basin is composed of Cascadian volcanic conglomerate, windblown sediment, flood deposits, and stream deposits. The conglomerates range from 100 to 200 feet thick and are made of gravels with boulders and lenses interlaid with volcanic tuff. The windblown sediment, also referred to as Portland Hills Silt, is comprised of mica, clay, and silt. It ranges in thickness from 5 feet to 120 feet. Catastrophic floods in the late Pleistocene deposited thick layers of Pleistocene sediments. Upwards of 40 floods are believed to have occurred during the late Pleistocene. Each flood deposited gravels, sands, and silts with total thicknesses ranging from 350 to 400 feet. Stream deposits are found along all major rivers in the Portland Basin, and are primarily composed of sand and silt along the Columbia and Willamette Rivers.

\subsubsection{Hydrogeology}

The hydrogeology of the study area is delineated by its aquifers and confining units. Aquifers are defined as geological units with significant water-bearing capacity. Confining units are defined as geological units that retard or restrict fluid flow. Groundwater flow is impacted by the presence of aquifers and confining units. A hydrogeologic unit defines a subsurface 
element that impacts groundwater movement, and may include multiple geologic units with similar water-bearing characteristics.

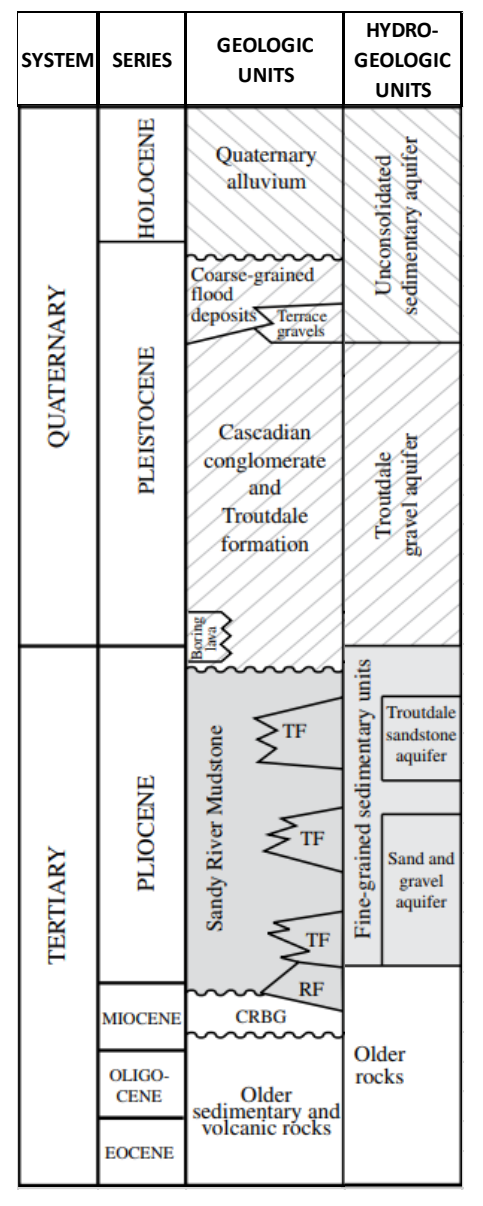

This study adapted the hydrogeologic units mapped by Swanson et al. (1993) for the Portland Basin. Swanson et al. (1993) described eight main units, listed in order from oldest to youngest: older rocks, sand and gravel aquifer, confining unit 2 , Troutdale sandstone aquifer, confining unit 1 , Troutdale gravel aquifer, and the unconsolidated sedimentary rock aquifer. Swanson et al. (1993) also include undifferentiated fine-grain sediments to describe areas where there was not enough information to distinguish confining unit 1 from confining unit 2 . This study includes five of the eight main units: confining unit 2 , Troutdale sandstone aquifer, confining unit 1 , Troutdale gravel aquifer, and the unconsolidated sedimentary rock aquifer. The relationship between the geology units and hydrogeology units is depicted as shown in Figure 10.

Figure 10: Relationship between the geology and hydrogeology in the Portland Basin (Conlon et al. 2005)

\subsubsection{Confining Unit 2}

Confining unit 2 is composed of clay and silt with striations of sand. The unit ranges in thickness from 200 feet to over 800 feet. The sand lenses can be used as water supply when other more permeable units are not available. The unit limits vertical flow in the aquifer and acts as a partial confining unit.

\subsubsection{Troutdale Sandstone Aquifer}

The Troutdale sandstone aquifer is made up of glassy sandstone and conglomerate with small areas of sand and silt. The unit ranges in thickness from 100 to $200 \mathrm{feet}$, and may extend to 400 feet in some areas. It is a significant aquifer unit, and is the main groundwater supply source for the Portland well field. It can produce upwards of 2500 gallons per minute. 


\subsubsection{Confining Unit 1}

Confining unit 1 is composed of sand, silt, and clay. It is typically under 200 feet thick. In some areas, the sand content can yield water supply for domestic use; however, the unit has low permeability and is generally not used as a water source.

\subsubsection{Troutdale Gravel Aquifer}

The Troutdale gravel aquifer is a consolidated gravel aquifer that is primarily made of cemented and sandy conglomerate with some lavas. The unit typically ranges from 100 feet to 400 feet thick, though can reach thicknesses of 800 feet in areas with lavas. The aquifer acts as an important water supply source for public, industrial, and domestic use with production capable of reaching 1000 gallons per minute.

\subsubsection{Unconsolidated Sedimentary Rocks}

The uppermost unit in the study area is the unconsolidated sedimentary aquifer. This unit extends to the ground surface over the entire study area with the exception of Kelly Butte and Powell Butte, which are part of the Troutdale gravel aquifer. The unit is predominantly composed of catastrophic flood deposits and stream deposits. The unit ranges in thickness from 50 to 100 feet, with some areas extending to 300 feet. It is the most productive waterbearing unit in the Portland Basin, and is capable of yielding up to 10,000 gallons per minute. 


\section{RESEARCH METHODS}

The methods employed in this study included data collection, model selection, modeling of surface-groundwater interactions, and analysis of model outputs.

This study used MODFLOW-NWT with the ModelMuse graphical user interface and UFZ package. MODFLOW-NWT is a Newtonian version of MODFLOW-2005 (Niswonger et al. 2011). In the Newtonian version, all model cells remain active throughout the simulation. This prevents convergence issues found in MODFLOW-2005 and allows cells to rewet after drying.

\subsection{Data Collection}

The model simulated the 318-day period from June 14, 1999 to April 26, 2000. Precipitation data was collected from City of Portland's HYDRA rainfall network. The Holgate rain gage at 4507 SE $136^{\text {th }}$ Ave, located approximately 1000 feet from the study area, was selected based on its proximity to the study area. Temperature data was obtained from the National Centers for Environmental Information (NCEI). Daily maximum and minimum temperatures for the 318-day model run were requested for the Portland Weather Forecast Office, which is located approximately 5 miles from the study area. Missing daily temperature records were obtained from the Portland International Airport daily summaries. Groundwater level data was collected from the National Water Information System for nine wells within the study area. Surface-water level data was also collected from the National Water Information System for Holgate Lake and Johnson Creek at Sycamore, Oregon. Land use data was collected from the U.S. Geological Survey StreamStats application. Hydrogeological data was obtained from borehole logs compiled by Swanson et al. (1993). Aquifer parameters were adapted from Morgan and McFarland (1996) and Conlon et al. (2005).

\subsection{Data Processing}

Hydrologic parameters provide the initial inputs into hydrological models. This study utilized precipitation and temperature data from City of Portland's HYDRA rain network and NCEI, respectively. 


\subsubsection{Precipitation}

Precipitation data was obtained from the Holgate rain gage, located at 4507 SE $136^{\text {th }}$ Ave. The gage was in operation from August 1998 to February 2012 with hourly data provided over the duration of its operation. Daily totals were calculated for the 318-day model run. Precipitation at the Holgate rain gage was assumed to be representative for the entire model domain.

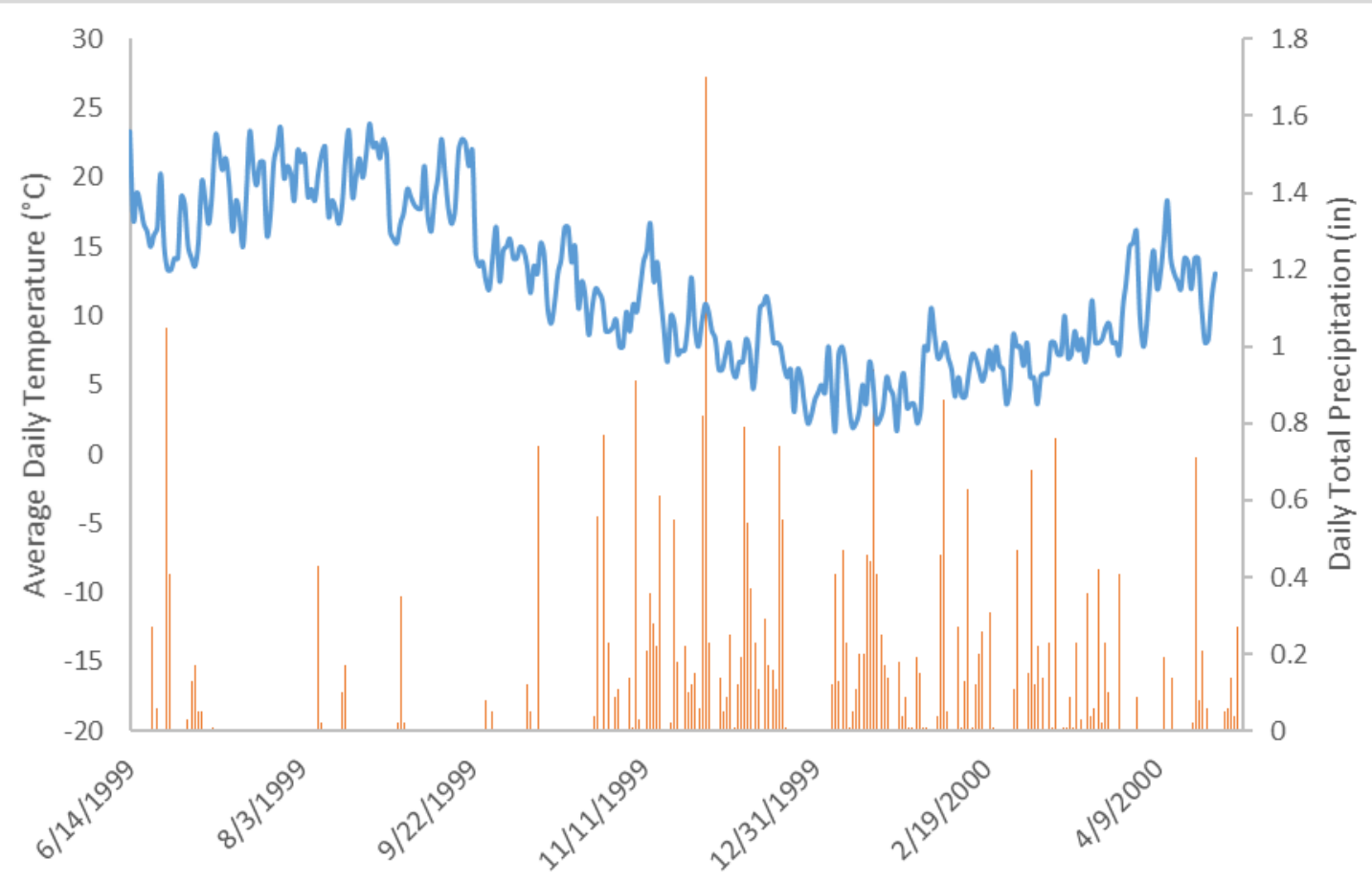

Days

Precipitation Temperature

Figure 11: Precipitation from Holgate rain gage and daily temperature from the Portland Weather Forecast Office

\subsubsection{Potential Evapotranspiration Estimation}

Evapotranspiration plays an important role in the hydrologic system and impacts both the unsaturated and saturated zones of subsurface systems. Evapotranspiration rates are a function of soil moisture and depth to water table. In MODFLOW-NWT, evapotranspiration is modeled by the UZF package using estimated potential evapotranspiration. Potential 
evapotranspiration describes the evapotranspiration rate that occurs when a sufficient water source is present.

Potential evapotranspiration can be estimated using the 1985 Hargreaves method for periods longer than a week (Hargreaves and Allen 2003).

$$
E T_{o}=0.0023 R_{a}(T C+17.8) T R^{0.50}
$$

Equation 1

In the Hargreaves method (Equation 1), $E T_{o}$ is the potential evapotranspiration (mm/day), $R a$ is the total incoming extraterrestrial solar radiation ( $\left.\mathrm{MJ} / \mathrm{m}^{2} \mathrm{day}\right), T C$ is the daily mean air temperature in Celsius, and $T R$ is the difference between the daily maximum air temperature and the daily minimum air temperature. The total incoming extraterrestrial solar radiation was estimated using the solar constant, solar declination, and time of year (Equation 2)

$$
R_{a}=\frac{1440}{\pi} G_{s c} d_{r}\left[\omega_{s} \sin \varphi \sin \delta+\cos \varphi \cos \delta \sin \omega_{s}\right] \quad \text { Equation } 2
$$

where $G_{s c}$ is the solar constant $\left(0.082 \mathrm{MJ} / \mathrm{m}^{2} \mathrm{~min}\right), d_{r}$ is the inverse relative Earth-Sun distance, $\omega_{s}$ is the sunset hour angle, $\varphi$ is the latitude in radians, and $\delta$ is the solar declination.

The calculated Hargreaves potential evapotranspiration was modified using the cropcoefficient approach to estimate the potential evapotranspiration values for the model inputs (Farg et al. 2012).

$$
P E T=K_{c} * E T_{o}
$$

Equation 3

where PET is the model input potential evapotranspiration and $K_{c}$ is the crop coefficient. The land cover of the study area was used to estimate the crop coefficient as 0.93 . This accounts for a weighted average of the forested and grass covered areas in the study area. 


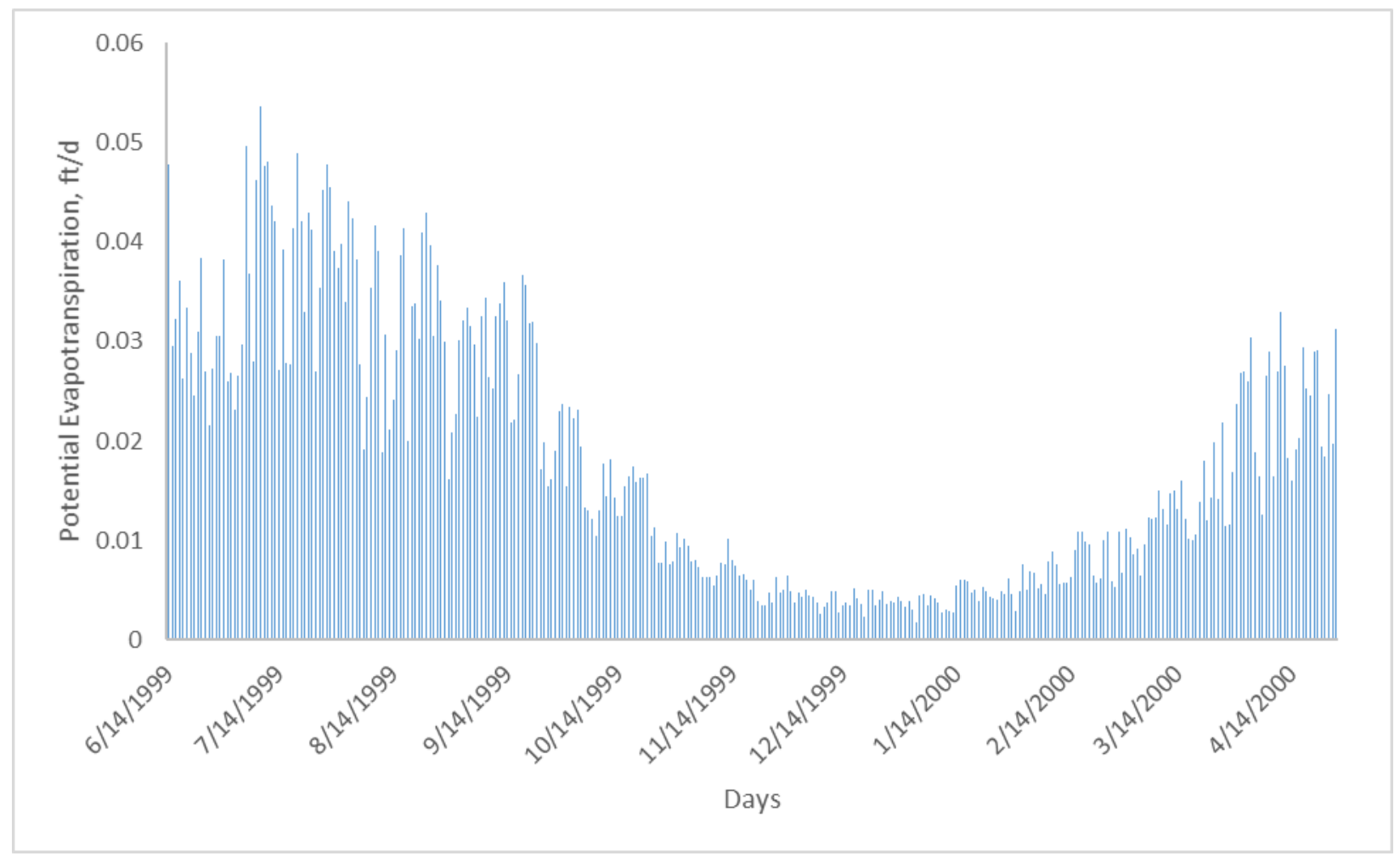

Figure 12: Potential evapotranspiration calculated using the Hargreaves Method

\subsubsection{Interception}

Interception describes the amount of precipitation that does not infiltrate into the subsurface. It is commonly defined as the amount of precipitation that is intercepted by vegetation. Interception is a function of numerous parameters including vegetation type, time of year, and storm intensity and was reported to equal approximately 24 percent for the study area (Rothacher 1963). A single interception percentage was assumed to be representative of the entire 318-day model run.

\subsubsection{Infiltration}

The infiltration rate was calculated as the difference between daily precipitation and interception. The UZF package converts infiltration rate into water content. When the infiltration rate input exceeds the saturated hydraulic conductivity, the UZF package sets the water content to the saturated water content (Niswonger et al. 2011). 


\subsection{Conceptual Model}

A conceptual model is a synthesis of site information that is used to generate a simplified representation of a groundwater system (Anderson et al. 2015). Generally, as the conceptual model more closely approximates field conditions, the likelihood of generating reasonable outputs from the numerical model increases. The conceptual model for the study area considered hydrogeologic units, aquifer parameters, hydrologic parameters, and model boundaries.

\subsubsection{Hydrogeologic units}

The conceptual model of the study area was adapted from Swanson et al. (1993). The bore log data for well 01/02E-14ABC was considered as representative of the study area. The study area was defined by a five layer model as outlined in Table 1.

Table 1: Conceptual model hydrogeologic units

\begin{tabular}{|c|c|c|}
\hline Formation & Layer Description & Thickness \\
\hline Unconsolidated Sedimentary Rocks & $1^{\text {st }}$ layer, unsaturated zone & Model top to 186 feet NAVD88 \\
\hline Troutdale Gravel Aquifer & $2^{\text {nd }}$ layer aquifer & 286 feet \\
\hline Confining Unit 1 & $3^{\text {rd }}$ layer aquitard & 100 feet \\
\hline Troutdale Sandstone Aquifer & $4^{\text {th }}$ layer aquifer & 150 feet \\
\hline Confining Unit 2 & $5^{\text {th }}$ layer aquitard & 600 feet \\
\hline
\end{tabular}

\subsubsection{Surface Water and Flow Directions}

A 1.1-mile section of Johnson Creek runs through the southeast portion of the model. The groundwater flow in the study area predominately flows north northwest towards the Willamette River.

\subsubsection{External and internal model physical boundaries}

Boundary conditions impact the movement of groundwater in the model and are considered an essential component of the model system (Franke et al. 1987). In this study, two types of boundary conditions were utilized: internal and external physical boundaries. 
The segment of Johnson Creek that flows through the model domain was used as an internal physical boundary. The Drain package was used to define the river segment. The Drain package is a head-dependent flux boundary. The package requires elevation and conductance per unit length parameters. The parameters were considered to be consistent over the 318-day duration of the model run. The elevation was determined as an average value between the river's elevation at the eastern entry point and southern exit point. The conductance was calculated as

$$
C=\frac{K L W}{M}
$$

Equation 4

where $C$ is the conductance, $K$ is the hydraulic conductivity of the river bed material, $L$ is the length of the river reach, $W$ is the width of the river, and $M$ is the thickness of the riverbed. The hydraulic conductivity of the river bed material was assumed to be consistent with the Troutdale gravel aquifer.

The external physical boundaries were considered to be consistent with the model domain boundaries. A default no-flow boundary condition was assigned to the model domain boundaries.

\section{$2.4 \quad$ Numerical Model}

\subsubsection{General Concepts}

Numerical modeling simulates groundwater flow using two general methods: steady-state and transient flow conditions. Under steady-state conditions, aquifer storage capacity does not change over time, while the converse is true under transient conditions. The three dimensional continuity equation is used to describe flow in the subsurface system.

$$
\frac{\partial}{\partial x}\left(K_{x} \frac{\partial h}{\partial x}\right)+\frac{\partial}{\partial y}\left(K_{y} \frac{\partial h}{\partial y}\right)+\frac{\partial}{\partial z}\left(K_{z} \frac{\partial h}{\partial z}\right)+W=S \frac{\partial h}{\partial t}
$$

Equation 5

Under steady-state conditions, $\frac{\partial h}{\partial t}=0$. 
Under transient conditions, $\frac{\partial h}{\partial t}>0$.

where $K_{n}$ is the hydraulic conductivity in the $n$ direction, $h$ is the total head, $W$ is a source/sink term, $S$ is storage capacity, and $t$ is time.

\subsubsection{Software Selection}

This study used MODFLOW-NWT with the ModelMuse graphical user interface to model surface-subsurface interactions. MODFLOW-NWT requires the use of the UZF package to model the movement of water and storage in the unsaturated zone. The unsaturated zone acts as a transitional flux boundary between surface water and groundwater systems. The UZF package divides infiltration into evapotranspiration and distributes recharge across the model domain. The UZF package makes underlying assumptions to solve a kinematic wave equation for unsaturated fluid flow (Ely and Kahle 2012). It is assumed that flow only occurs under gravity-driven gradients and that hydraulic properties are consistent within each vertical column between the base of soil and the water table.

The UZF package requires evapotranspiration demand, infiltration rate, extinction depth, and extinction water content input parameters for each stress period. Evapotranspiration demand and infiltration rate were estimated as described previously (see sections 2.3.2 and 2.3.3). The parameters were assumed to be consistent for each day of each month. Stress periods were defined on a calendar month basis for a total of 11 stress periods over the 318day simulation. Extinction depth describes the lower limit of evapotranspiration. In this study, extinction depth was assumed to be consistent with the maximum root depth. The Gridded Soil Survey Geographic database was used to estimate the extinction depth at a depth of 5 feet. The extinction depth was assumed to be consistent throughout the model domain. The extinction water content describes the lower limit of water content for evapotranspiration, which is the field capacity of the unsaturated zone. The extinction water content was estimated as 0.2 . 


\subsubsection{Grid design}

The model was constructed using a uniform grid design measuring 3 miles by 2 miles. The grid design was consistent with the rectangular survey system. The study area covered T01S R02E sections 10 through 15. The grid was composed of 105 rows and 160 columns. It was aligned with geographic referencing in ModelMuse using EPSG 3855.

\subsubsection{Structural Model}

The model top was defined using the three feet Lidar digital elevation model (DEM) for the Portland metropolitan area (Figure 13). This dataset was obtained from the Center for Spatial Analysis and Research in the Geography Department at Portland State University. Five different layers define the model and represent the hydrogeologic units. The model layers were defined using borehole logs from well 01S/02E-14ABC.

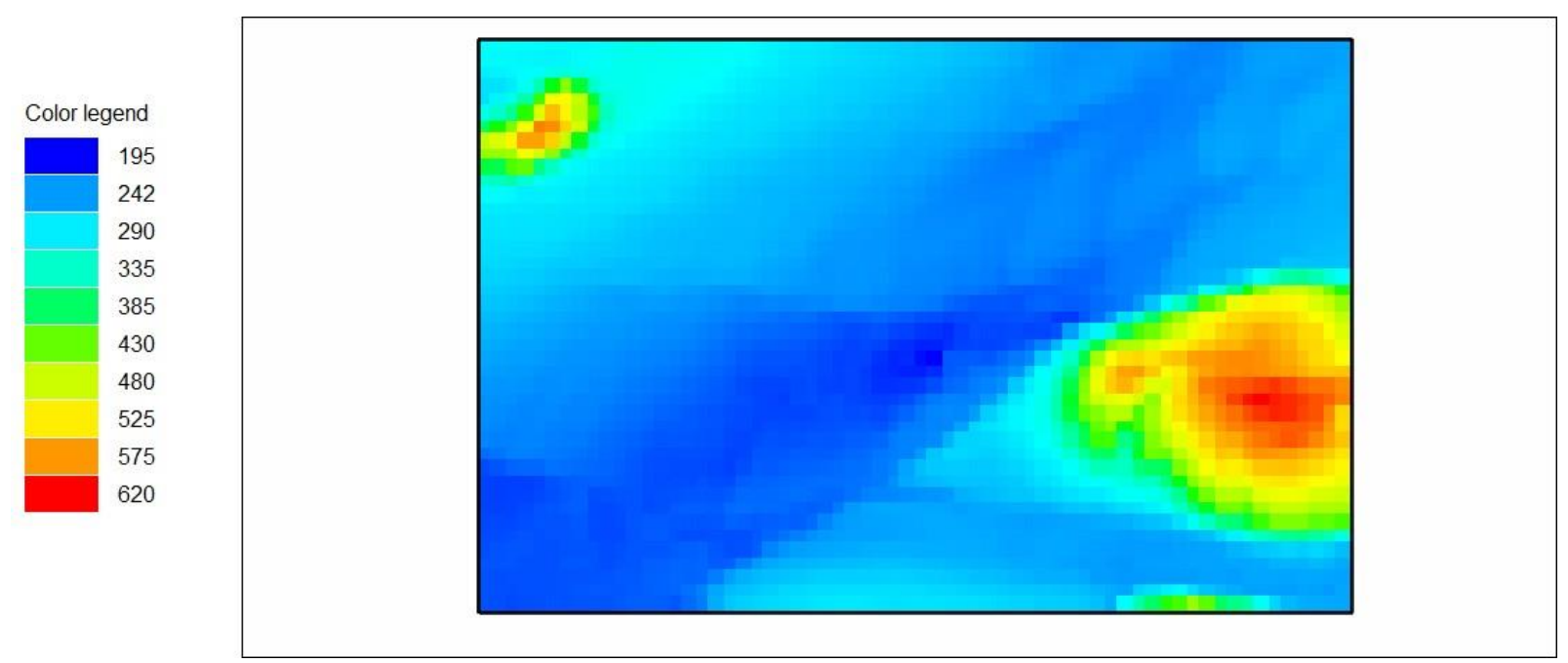

Figure 13: Digital Elevation Model (DEM) of the study area with elevation in feet

\subsubsection{Driving Forces}

The driving forces of a model are parameters that affect change in model outputs. Driving forces in this study include precipitation, interception, infiltration, and potential evapotranspiration. 


\subsubsection{System Parameterization}

This study used the UZF package, the Upstream Weighting package, and the Drain package. The Upstream Weighting package was used to define the horizontal and vertical conductivities, specific storage, and specific yield. The UZF package selected the unconsolidated sedimentary rock layer as the recharge and discharge location for the model (NUZTOP) with vertical hydraulic conductivity specified (IUZFOPT). The model was set to simulate evapotranspiration (IETFLG). The default values of 15 trailing waves (NTRAIL2) and 20 wave sets (NSETS2) were used. The waves were used to simulate changes in the infiltration rate when the unsaturated flow equation was solved. The waves develop over time under the influence of gravity to establish the water content at each time and depth. The UZF package uses the Brooks-Corey function to convert saturated hydraulic conductivity to unsaturated values. A value of 3.5 was assumed for the Brooks-Corey epsilon (Brooks and Corey 1964). The UZF package uses the Brooks-Corey function to calculate unsaturated hydraulic conductivity (Equation 6)

$$
K(\theta)=K_{s}\left[\frac{\theta-\theta_{r}}{\theta_{s}-\theta_{r}}\right]^{\varepsilon}
$$

where $K(\theta)$ is the unsaturated hydraulic conductivity as a function of water content, $K_{S}$ is the saturated hydraulic conductivity, $\theta_{r}$ is the residual water content, $\theta_{s}$ is the saturated water content, and $\varepsilon$ is the Brooks-Corey epsilon (Niswonger et al. 2006).

The maximum unsaturated vertical hydraulic conductivity was set at 2 feet/day based on the assumed parameters of the unconsolidated sedimentary rock layer. The initial unsaturated water content was set at 0.3 . The saturated water content was assumed equivalent to porosity, and a value of 0.31 was assumed (Snyder et al. 1996). Hydraulic conductivity and storage values were adapted from Morgan and McFarland (1996) and Conlon et al. (2005) as defined in Table 2 . The hydraulic conductivities in the unconsolidated sedimentary rock layer ranged from $1 \mathrm{ft} / \mathrm{d}$ to $282 \mathrm{ft} / \mathrm{d}$ (Figure 14). Values were estimated for each section as 
defined by the rectangular survey system in combination with maps adapted from Morgan and McFarland (1996).

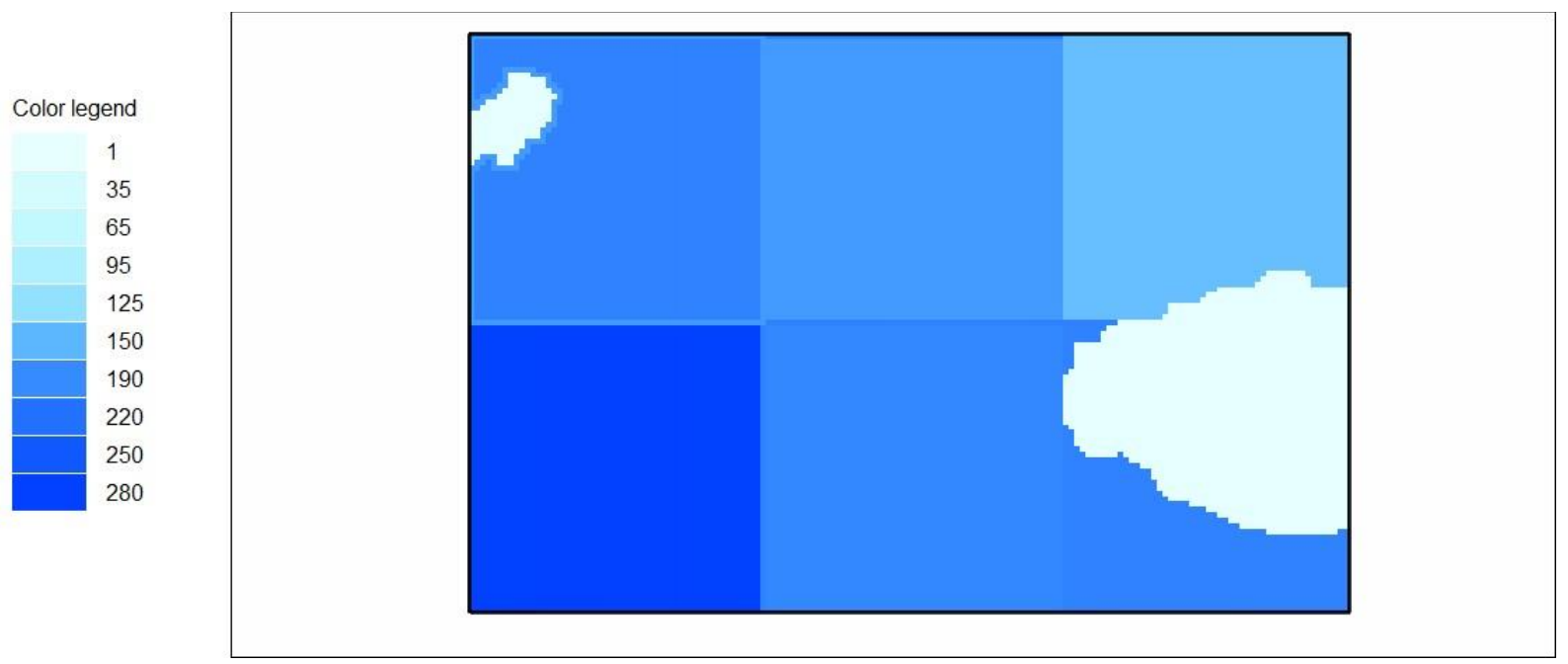

Figure 14: Horizontal hydraulic conductivity (feet/day) in the Unconsolidated Sedimentary Rock layer

Table 2: Hydraulic Conductivity and Storage Parameters

\begin{tabular}{|c|c|c|c|c|}
\hline \multicolumn{1}{|c|}{ Formation } & $\mathbf{K}_{\mathbf{x}, \mathbf{y}}(\mathbf{f t} / \mathbf{d})$ & $\mathbf{K}_{\mathbf{z}}(\mathbf{f t} / \mathbf{d})$ & Specific Storage & Specific Yield \\
\hline Unconsolidated Sedimentary Rocks & $1-282$ & 2 & 0.003 & 0.18 \\
\hline Troutdale Gravel Aquifer & 7 & 2 & 0.0008 & 0.21 \\
\hline Confining Unit 1 & 4 & 0.1 & 0.00005 & 0.05 \\
\hline Troutdale Sandstone Aquifer & 15 & 0.1 & 0.00024 & 0.27 \\
\hline Confining Unit 2 & 1 & 0.1 & 0.00005 & 0.03 \\
\hline
\end{tabular}

\subsubsection{State Variables}

This study utilized groundwater heads from nine wells as state variables. The observed hydraulic heads at nine wells in the study area from June 14th 1999 were used to calibrate the model (Figure 15). 


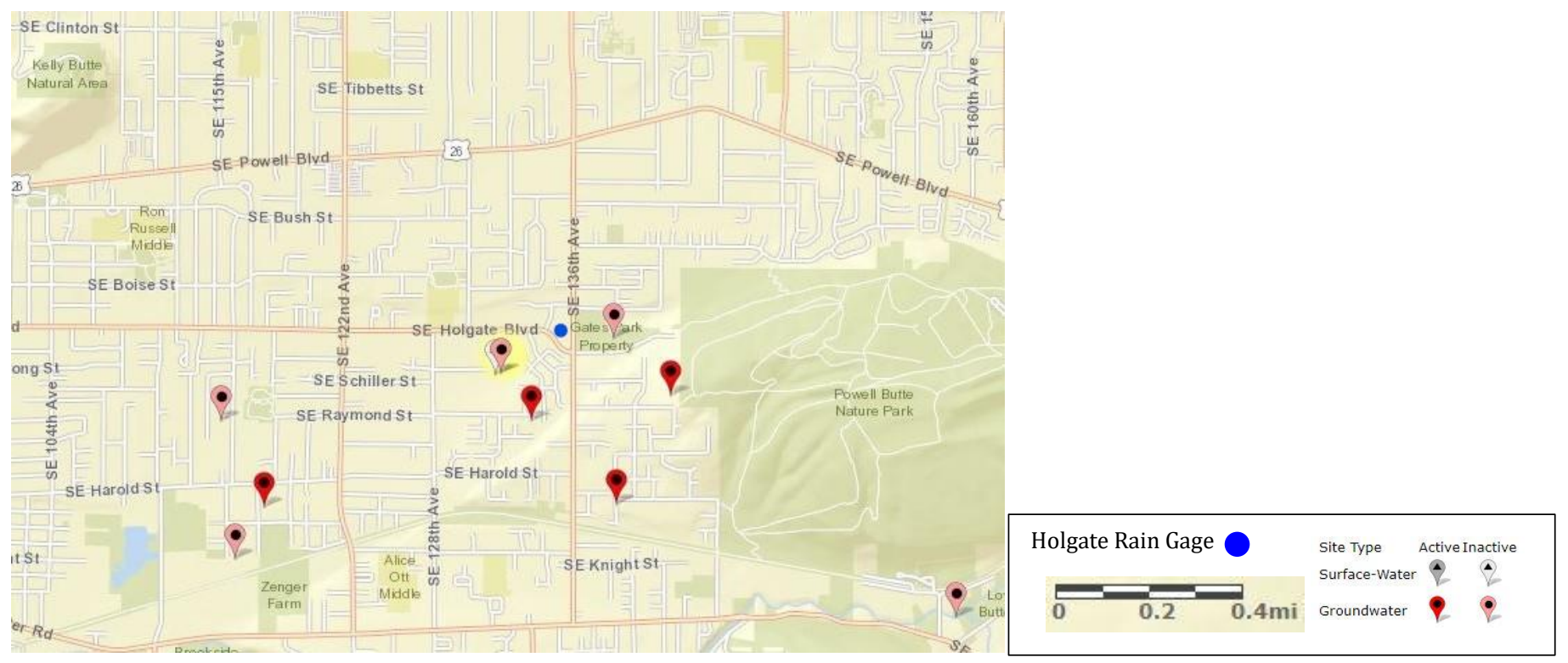

Figure 15: Model domain and wells used for initial conditions (NWIS Site Information for Oregon: Site Inventory)

\subsubsection{Time Discretization and Initial Conditions of Transient Model}

The study used feet as the length measurement and days as the time measurement. The model simulated the 318-day period from June $14^{\text {th }}, 1999$ to April $26^{\text {th }}, 2000$. The model duration was defined by 11 stress periods, with each calendar month representing one stress period. The initial conditions for the model were defined by the observed head levels at nine wells in the study area on June $14^{\text {th }}, 1999$. The initial head distribution was interpolated by the model (Figure 16).

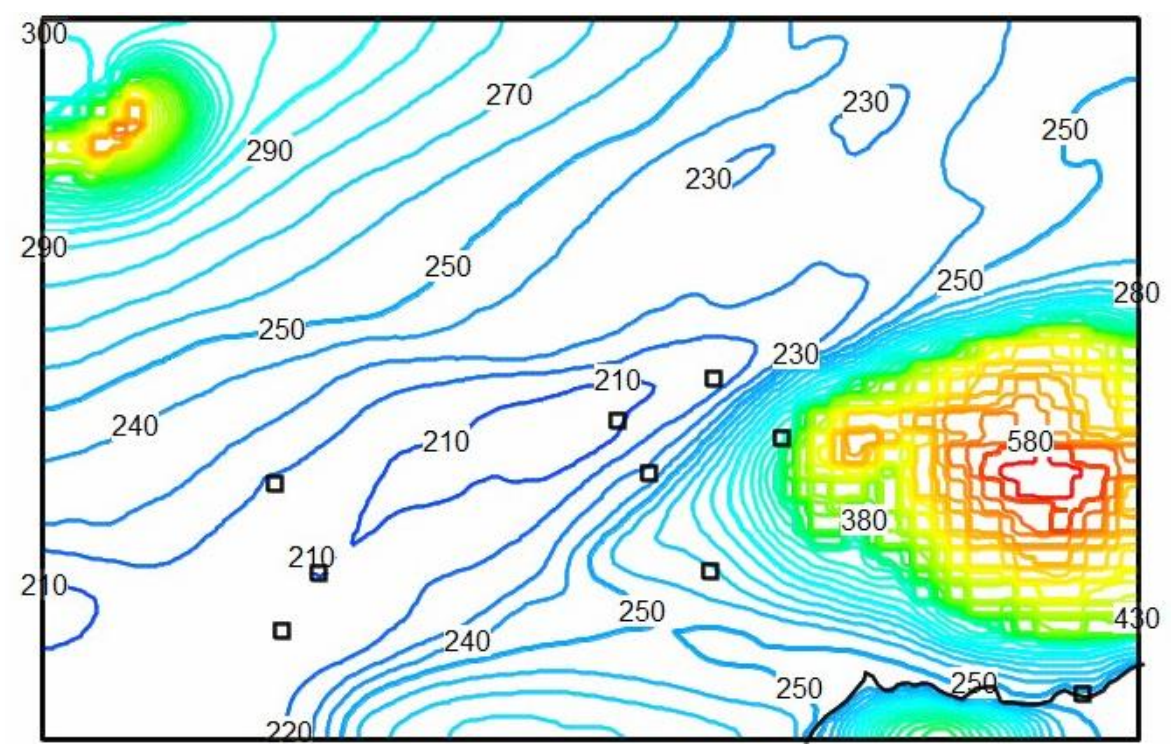

Figure 16: Initial head distributions, June 14, 1999 


\section{RESULTS AND DISCUSSION}

\subsection{Precipitation and Holgate Lake}

The cumulative precipitation from Holgate rain gage per water year (WY) from WY 1999 to WY 2011 was analyzed relative to the net groundwater level rise at well 01/02E-14ABC. Lee and Snyder (2009) compared cumulative precipitation at the Portland International Airport to net groundwater level rise from WY 1999 to WY 2006 and calculated an $\mathrm{R}^{2}$ of 0.63 . Using the Holgate rain gage, this study calculated an R² of 0.51 from WY 1999 to WY 2006 (Figure 17). When the analysis period was extended to include all available data from the Holgate rain gage to $W Y 2011$, the calculated $\mathrm{R}^{2}$ was 0.24 (Figure 18). The analyses are consistent in capturing a degree of uncertainty. As the sample size was increased, the degree of uncertainty in the relationship between precipitation and groundwater levels at Holgate Lake increased. While precipitation is likely a contributing factor to the appearance of Holgate Lake, other factors such as antecedent moisture conditions, aquifer properties and the overall degree of interconnected fluid flow between the multiple aquifers in the area, evapotranspiration, and the overall hydrodynamics of subsurface flow also likely contribute to the appearance of the lake.

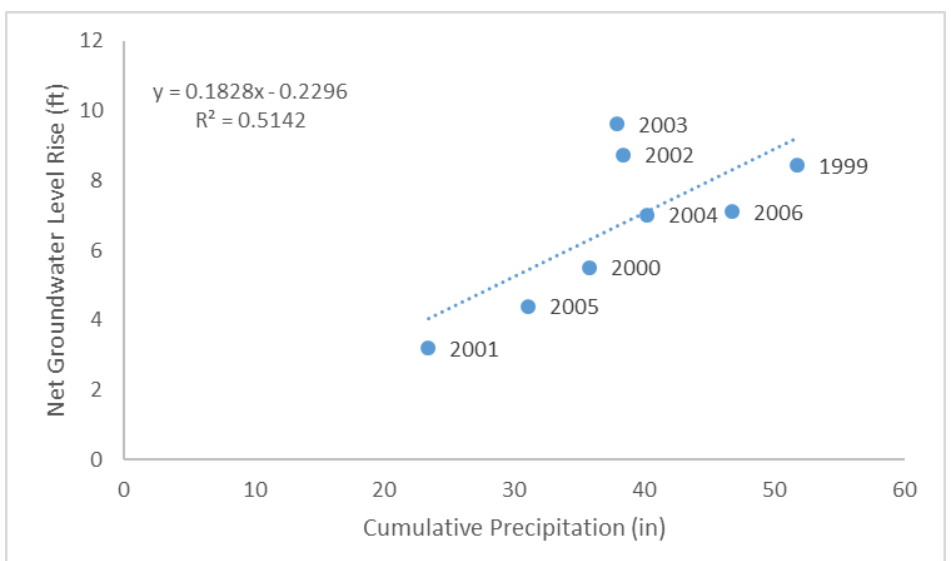

Figure 17: Relation between net annual rise in groundwater level at well 01S/02E-14ABC and cumulative WY precipitation at the Holgate rain gage from WY 1999 to WY 2006

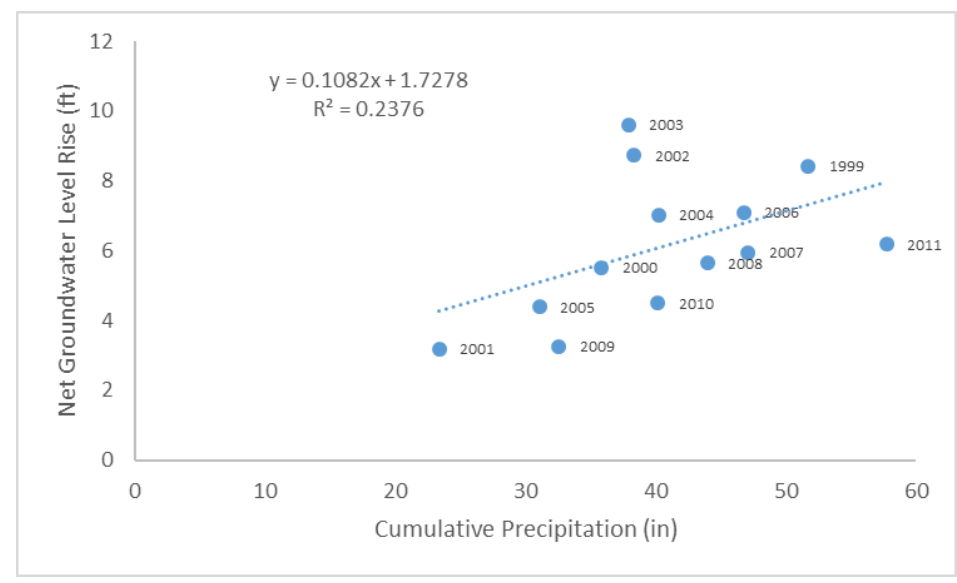

Figure 18: Relation between net annual rise in groundwater level at well 01S/02E-14ABC and cumulative WY precipitation at the Holgate rain gage from WY 1999 to WY 2011 


\subsection{Error Assessment and Groundwater Heads}

The root mean square error (RMSE) was used to assess the model outputs where $n$ is the number of observations, $H_{\text {obs }}$ is the observed head, and $H_{\text {sim }}$ is the model-simulated head (Equation 7).

$$
R M S E=\sqrt{\frac{1}{n} \sum\left(H_{o b s}-H_{s i m}\right)^{2}}
$$

Equation 7

The total RMSE for the base model equaled 17.37 for the observations at well 01S/02E$14 \mathrm{ABC}$ and well 01S/02E-14BAD. The residuals ranged from -53.89 feet on day 8 to 5.80 feet on day 295 for the two wells (Figure 19). The residuals were analyzed relevant to the order in which the data were collected. The broad range in residuals and evident trend observed in the residual vs. order plot indicates error in the model. The visible trend shown in Figure 19 indicates serial correlation. The error terms are not considered independent and suggests that the model can be improved upon.

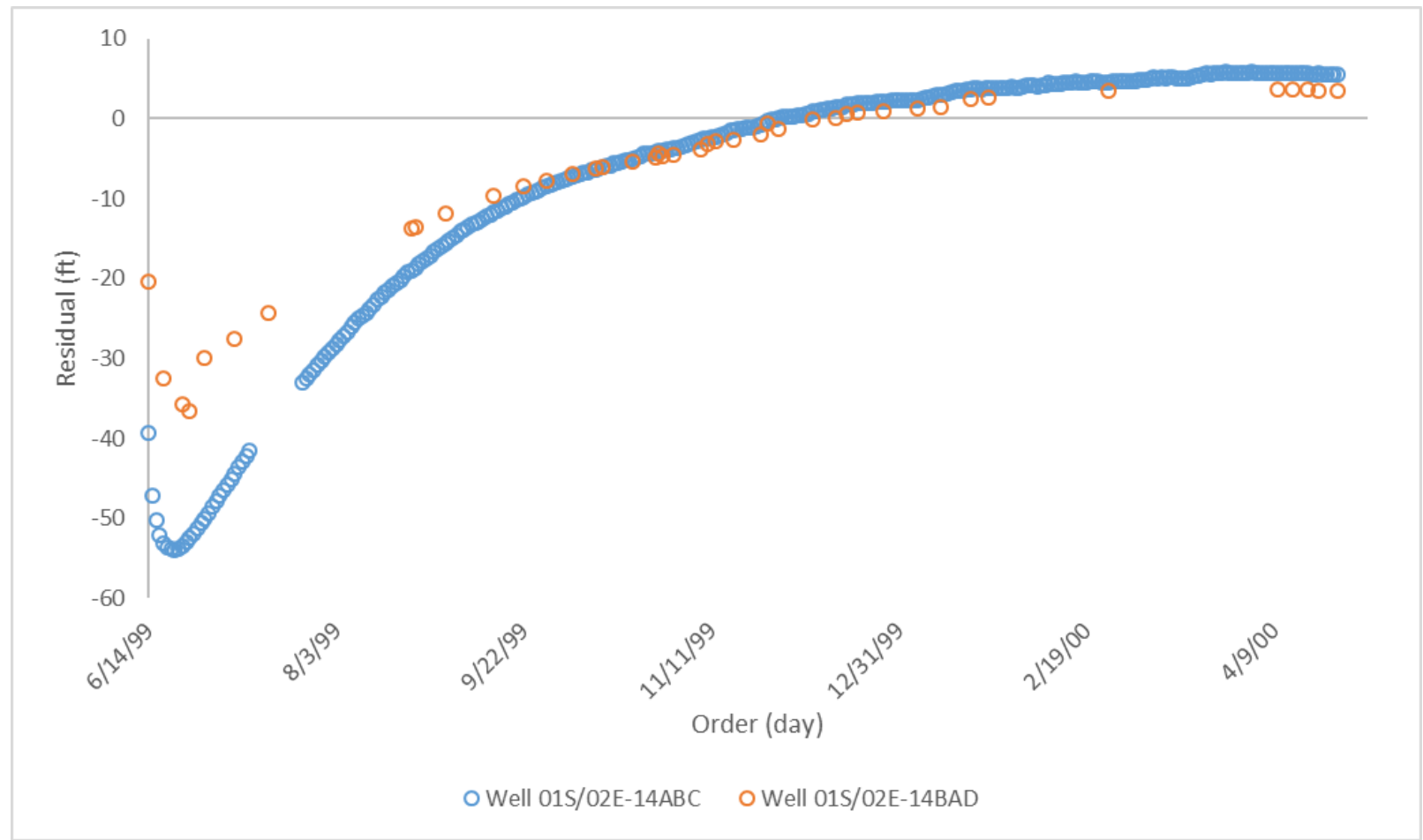

Figure 19: Residuals vs. simulated order for well 01S/02E-14ABC and well 01S/02E-14BAD 
When observed heads were compared to simulated heads, as shown in Figure 20, the data displayed two separate trends: a positive slope for the earlier half of the model and a negative slope for the latter half of the model. For the duration of the model run, the $\mathrm{R}^{2}$ was 0.10 for well 01S/02E-14ABC and 0.02 for well 01S/02E-14BAD (Figure 20).

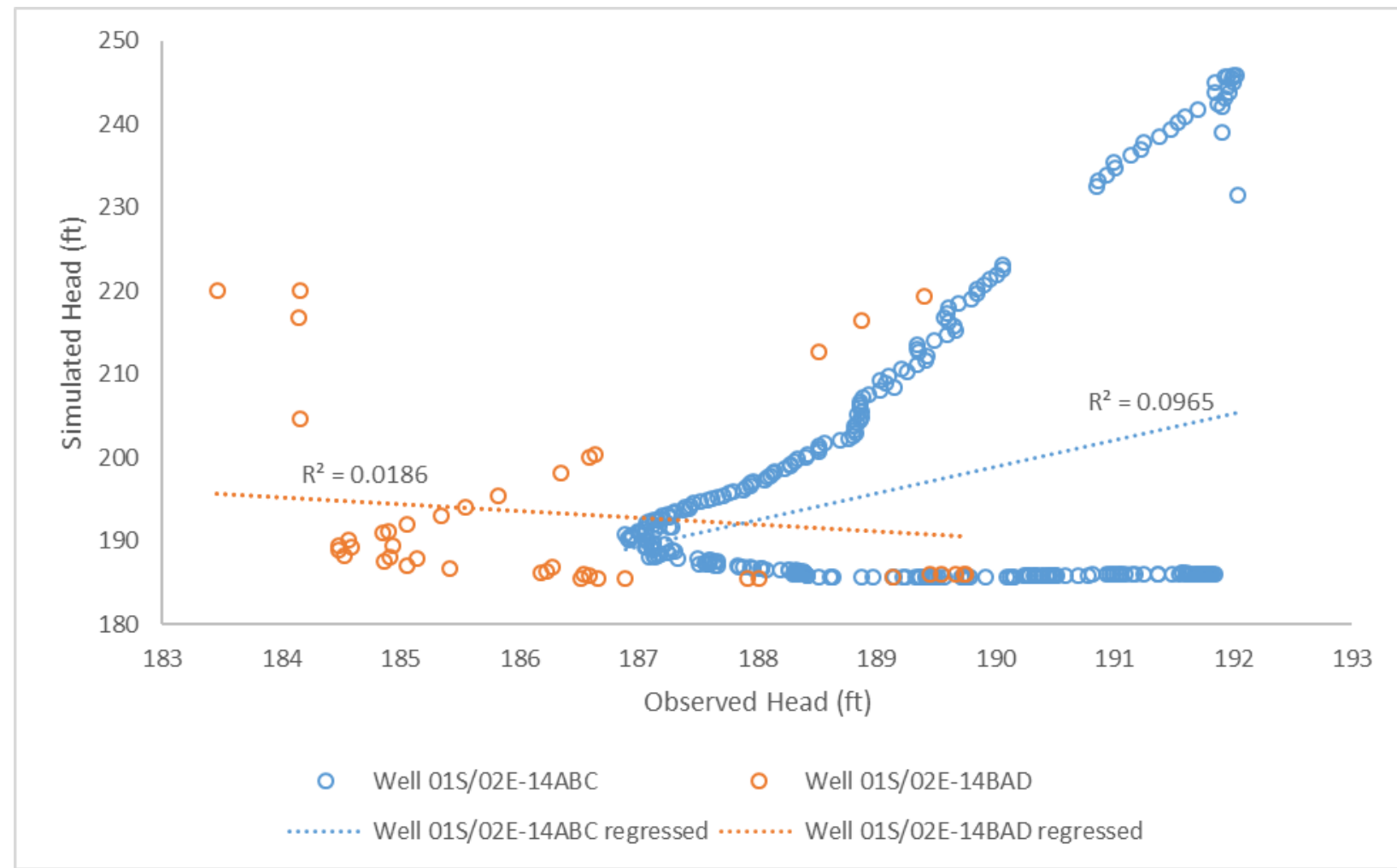

Figure 20: Simulated vs. observed heads at well 01S/02E-14ABC and well 01S/02E-14BAD for the 318-day model run

The data was then considered by dividing the model into two analysis periods: day 1 to day 150 and day 150 to day 318. The two analysis periods were selected based on the slope change observed in Figure 20. For the day 1 to day 150 analysis, the $\mathrm{R}^{2}$ was 0.98 for well 01S/02E-14ABC and 0.14 for well 01S/02E-14BAD (see Figure 21). 


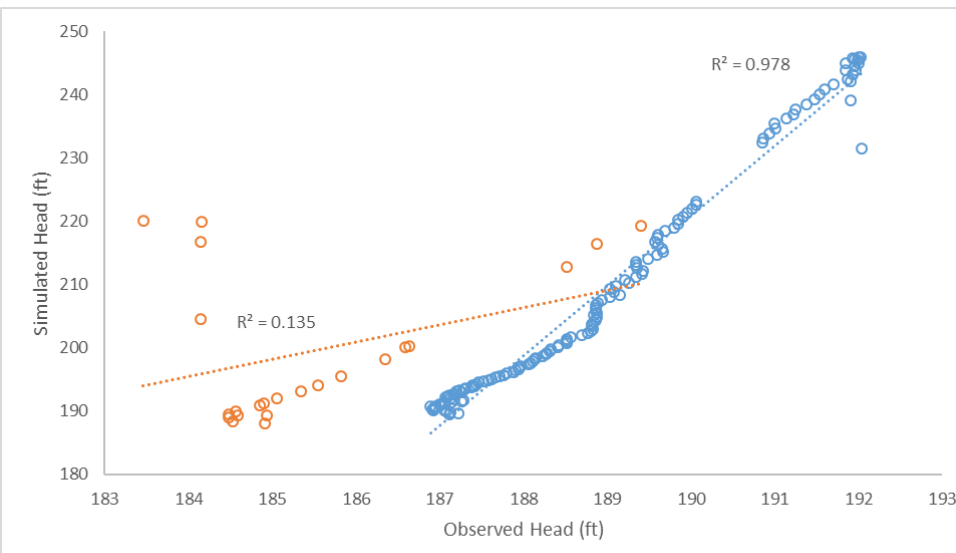

o Well 01S/02E-14ABC O Well 01S/02E-14BAD

Figure 21: Simulated vs. observed heads at well 01S/02E-14ABC and well 01S/02E-14BAD for day 1 to day 150

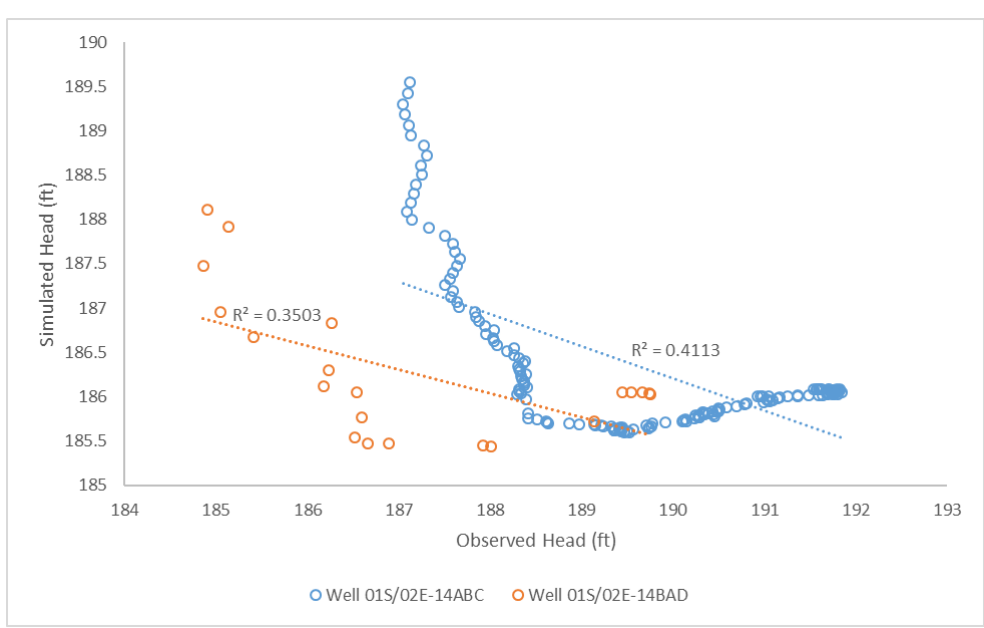

Figure 22: Simulated vs. observed heads at well 01S/02E-14ABC and well 01S/02E-14BAD for day 150 to day 318

For the day 150 to day 318 analysis, the $\mathrm{R}^{2}$ was 0.41 for well $01 \mathrm{~S} / 02 \mathrm{E}-14 \mathrm{ABC}$ and 0.35 for well 01S/02E-14BAD as shown in Figure 22. The variability in the regression results between the two wells indicates that the model has a spatial bias. The well in the lakebed has significantly lower $\mathrm{R}^{2}$ values than the well 0.2 miles from Holgate Lake. This indicates a calibration error in the model. The variability between the early and latter stages of the model run suggests that temporal trends may impact the model. The results were then considered on a seasonal basis (Figure 23).

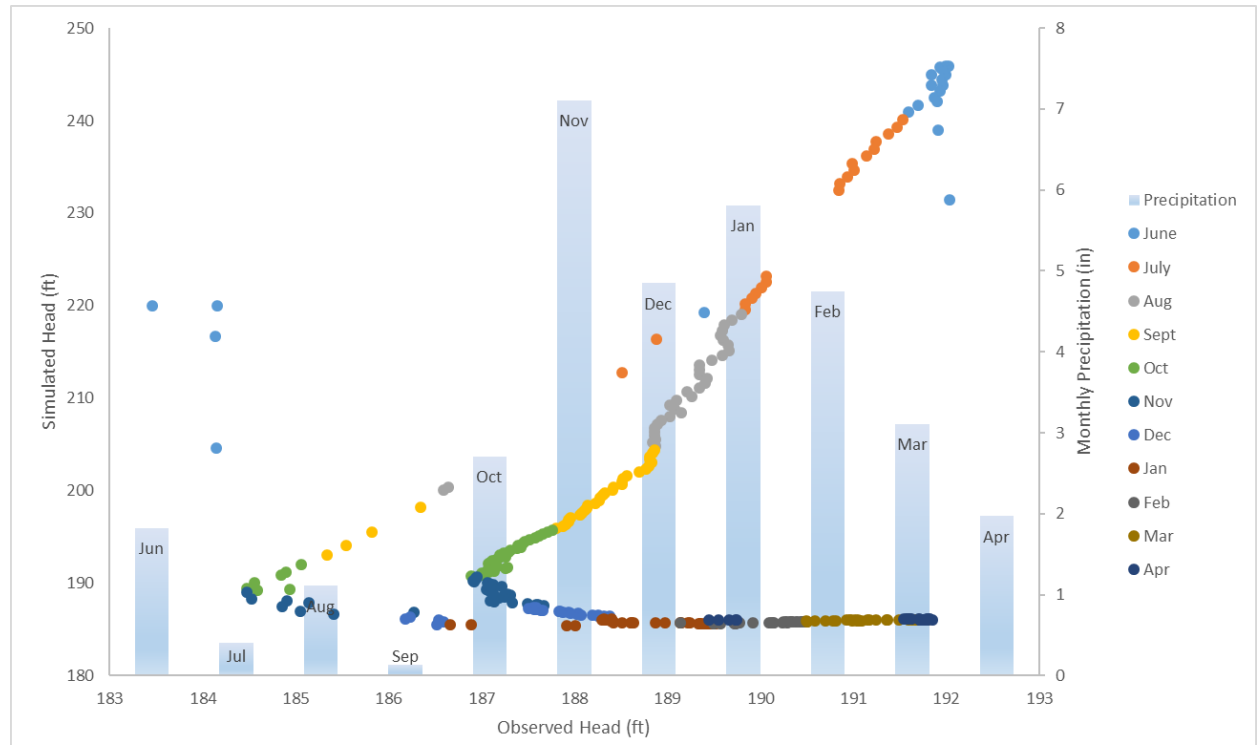

Figure 23: Simulated vs. observed heads at well 01S/02E-14ABC and well 01S/02E-14BAD for each modeled month presented with cumulative monthly precipition 
During the 318-day model run, September 1999 had the lowest monthly precipitation at 0.13 inches and November 1999 had the highest precipitation at 7.11 inches. Regression analysis was conducted on a monthly basis over the course of the model run. The months with less precipitation had higher $\mathrm{R}^{2}$ values than the months with more precipitation. For example, during July when the second least amount of precipitation fell, the $\mathrm{R}^{2}$ was 0.95 (Figure 24). During January when the second highest amount of precipitation fell, the $\mathrm{R}^{2}$ was 0.005 (Figure 26). The weaker correlation between observed and simulated values in months with more precipitation limits the models ability to accurately predict the appearance of the lake. The variability in regression results suggests bias in the model. Infiltration rate was assumed constant over each calendar month stress period. This potentially limited the model's ability to respond to parameters impacted at the daily and subdaily time step, such as infiltration and evapotranspiration.

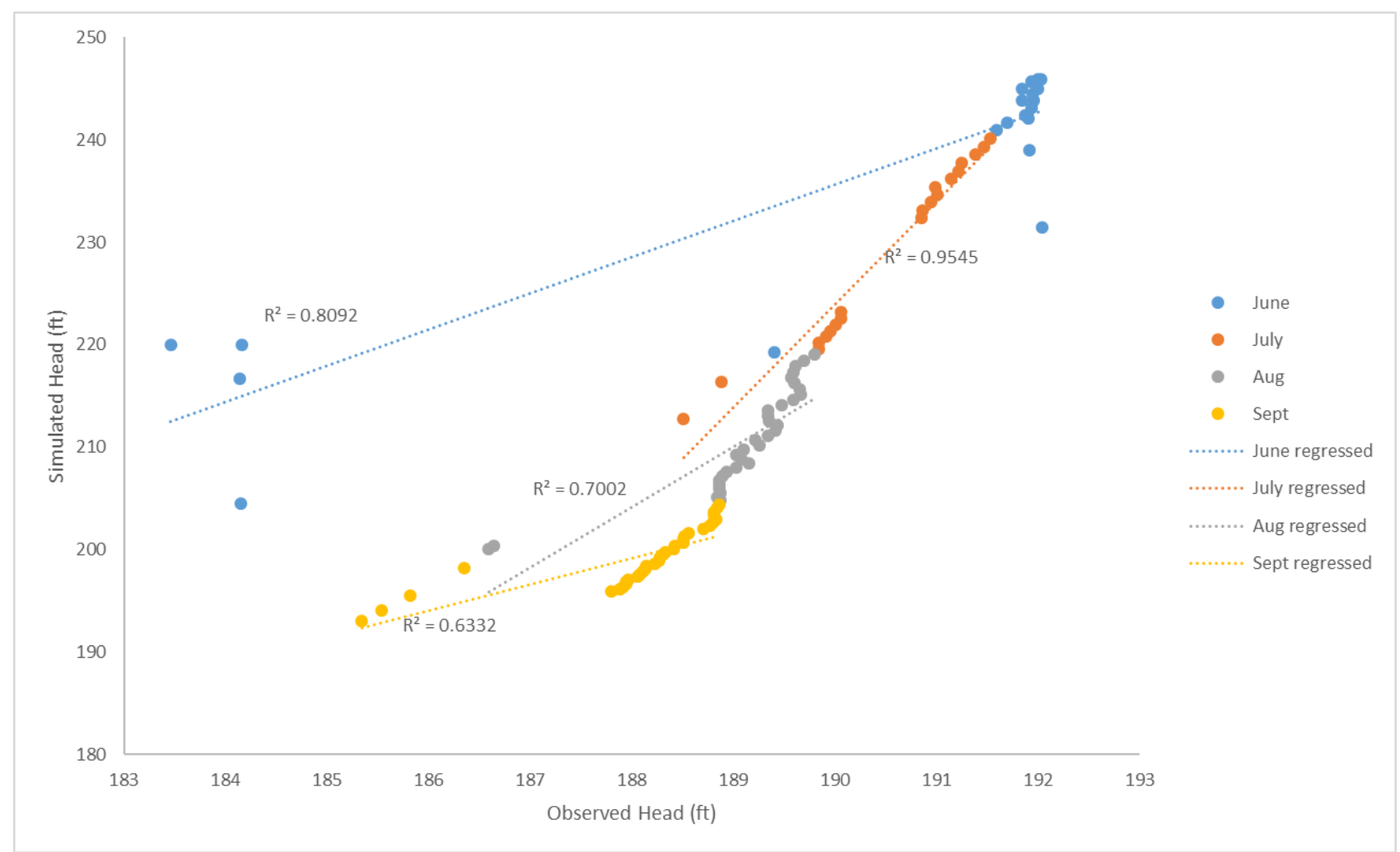

Figure 24: Monthly regression analysis results of simulated vs. observed heads at well 01S/02E-14ABC and well 01S/02E-14BAD, June 1999 to September 1999 


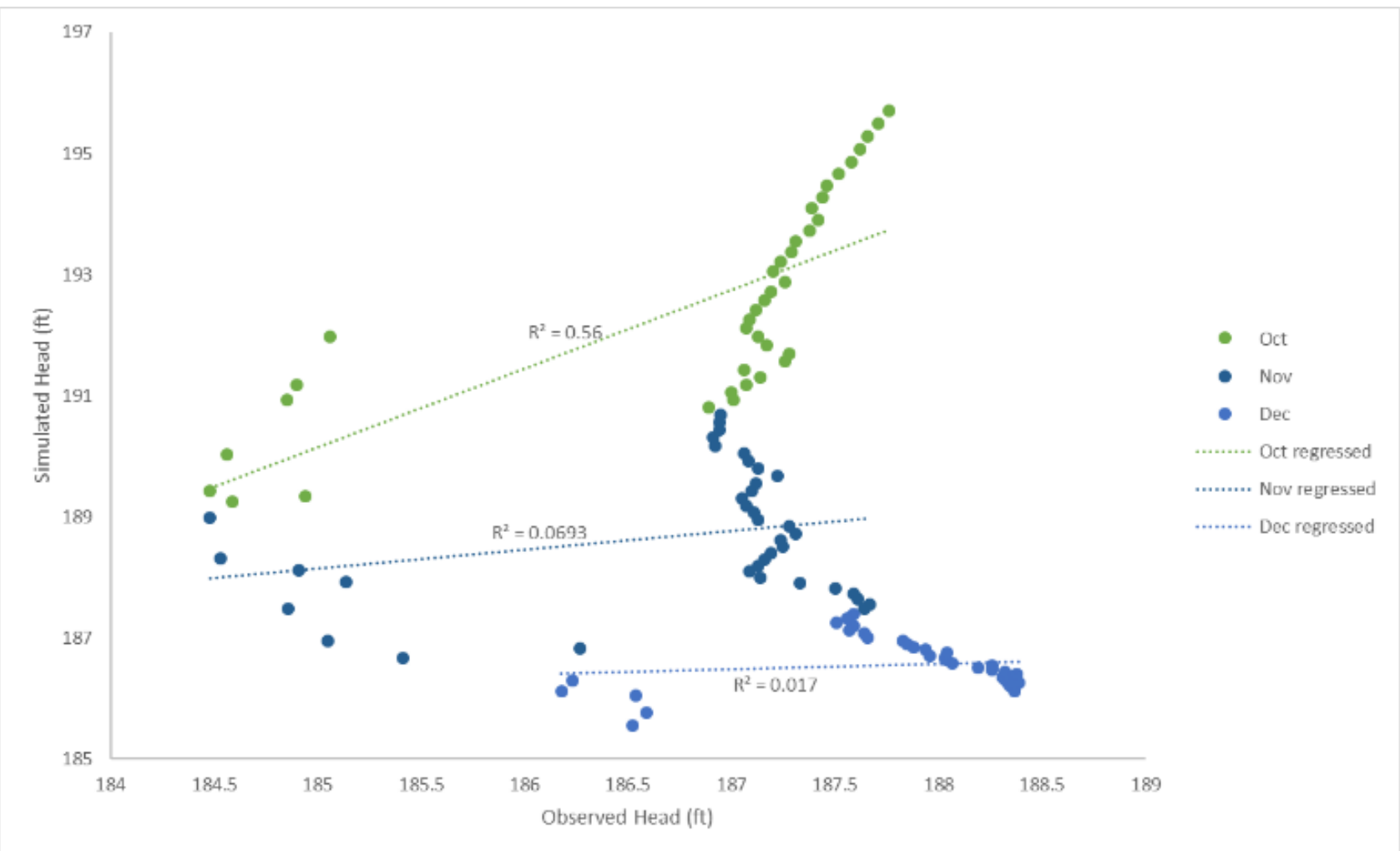

Figure 25: Monthly regression analysis results of simulated vs. observed heads at well 01S/02E-14ABC and well 01S/02E-14BAD, October 1999 to December 1999

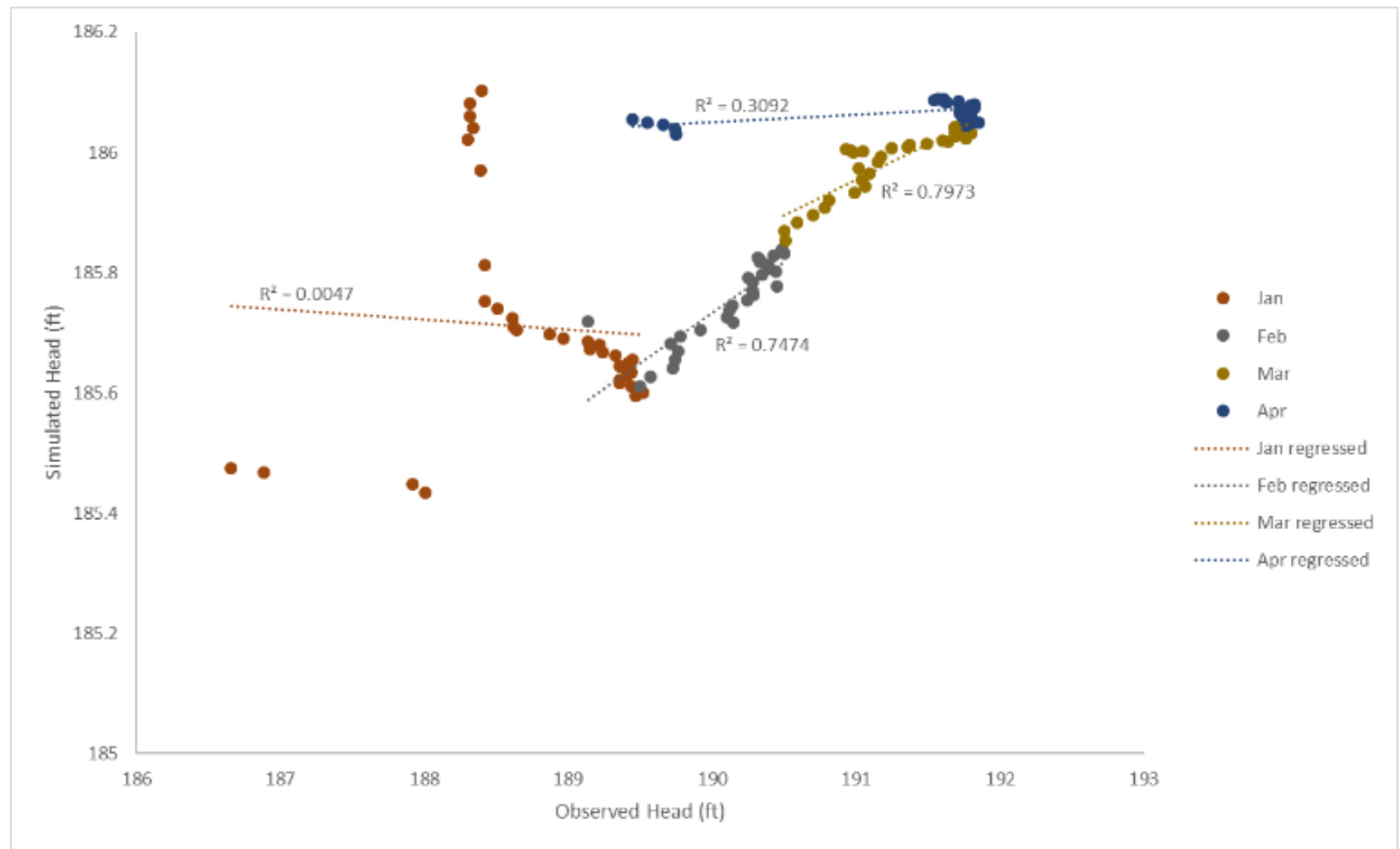

Figure 26: Monthly regression analysis results of simulated vs. observed heads at well 01S/02E-14ABC and well 01S/02E-14BAD, January 2000 to April 2000 


\subsection{Sensitivity Analysis}

Sixty model runs were conducted to test the sensitivity of model parameters. The model was most sensitive to aquifer parameters such as horizontal hydraulic conductivity (HK), vertical hydraulic conductivity (VK), and storage capacity (Ss, Sy). The model was less sensitive to hydrologic variables. For example, varying the estimates for infiltration rates (Inf) resulted in minimal changes in the measured RMSE. The difference between the base model RMSE and multiple parameters tested for sensitivity are shown in Figure 27.

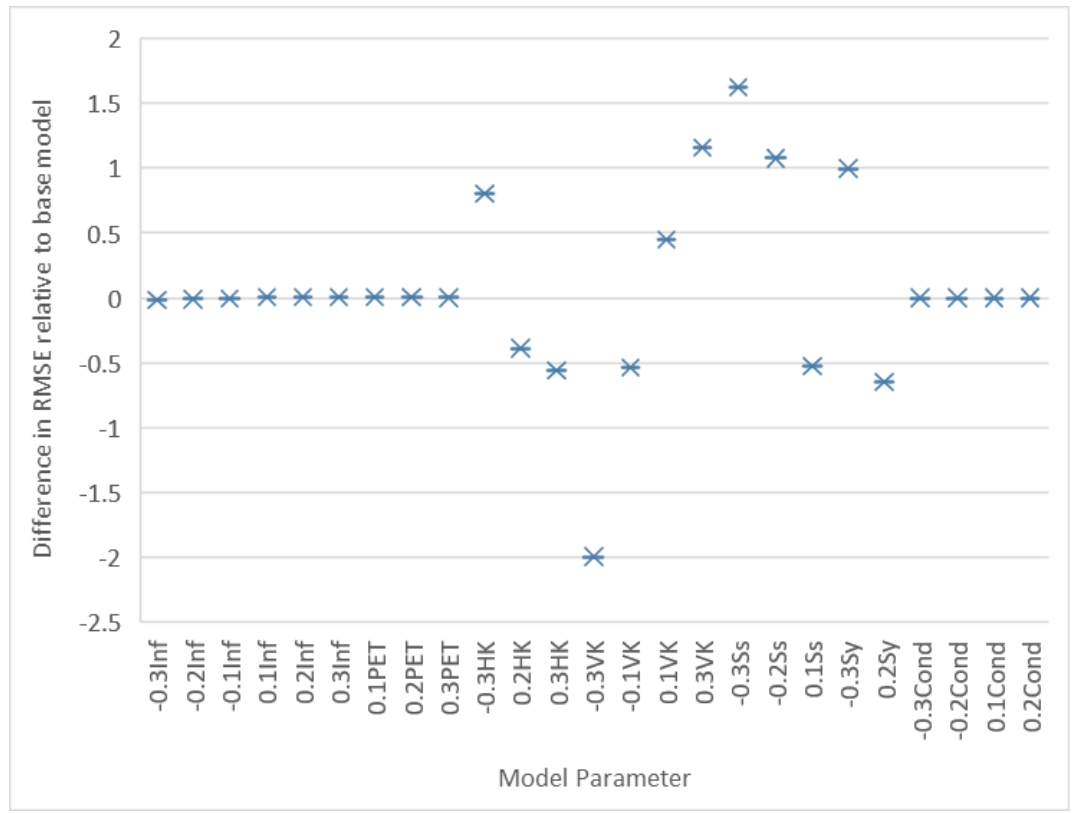

Figure 27: Sensitivity analysis of model input parameters

Reductions in vertical hydraulic conductivity (VK) had the greatest impact on the model, followed by reductions in specific storage (Ss). Changes in horizontal hydraulic conductivity (HK) and specific yield (Sy) resulted in a moderate influence on the model (Figure 28). Changes in infiltration (Inf), evapotranspiration (PET), and surface-water conductance (Cond) had a negligible impact on the model (Figure 29). 


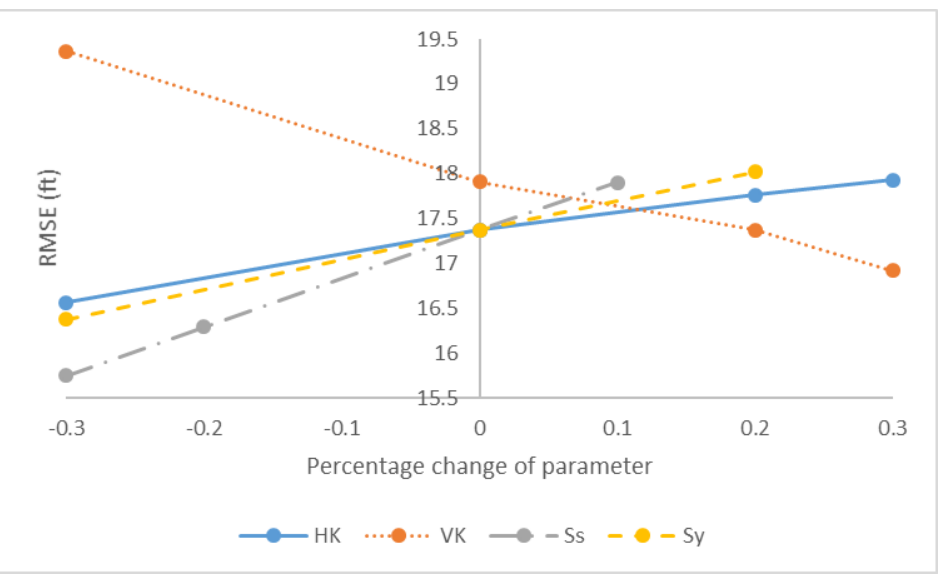

Figure 28: Sensitivity of aquifer parameters

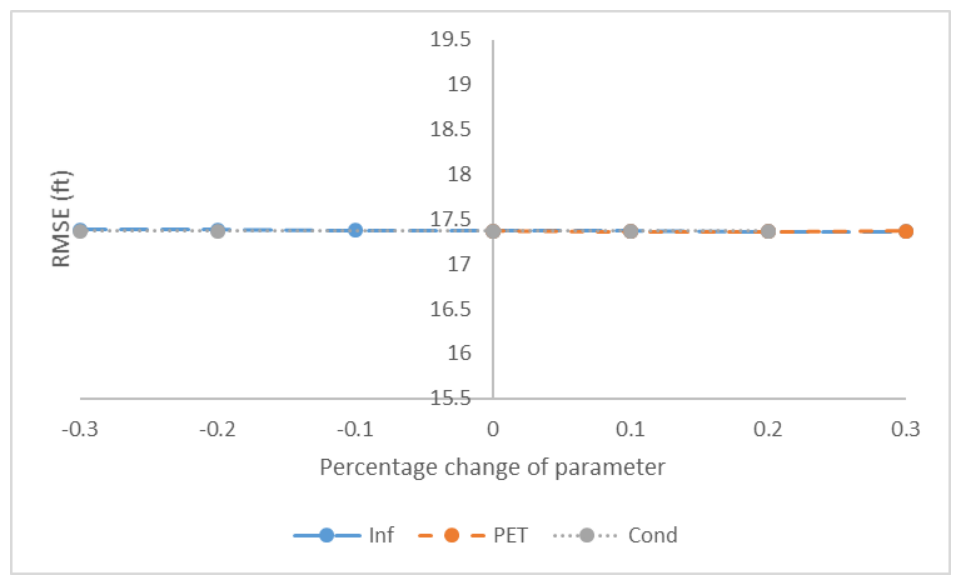

Figure 29: Sensitivity of hydrologic parameters

The variables used in the UZF package, such as the Brooks-Corey epsilon (BCEp), extinction depth (ETD), initial unsaturated water content (IUW), and evapotranspiration extinction water content (ETW), were tested for sensitivity (Figure 30). Changes in the variables had a negligible impact on the measured RMSE. It may be of interest to note that the extinction depth had the greatest impact of the UZF package parameters tested; however, the impact was negligible in comparison to the aquifer parameters discussed above (Figure 31).

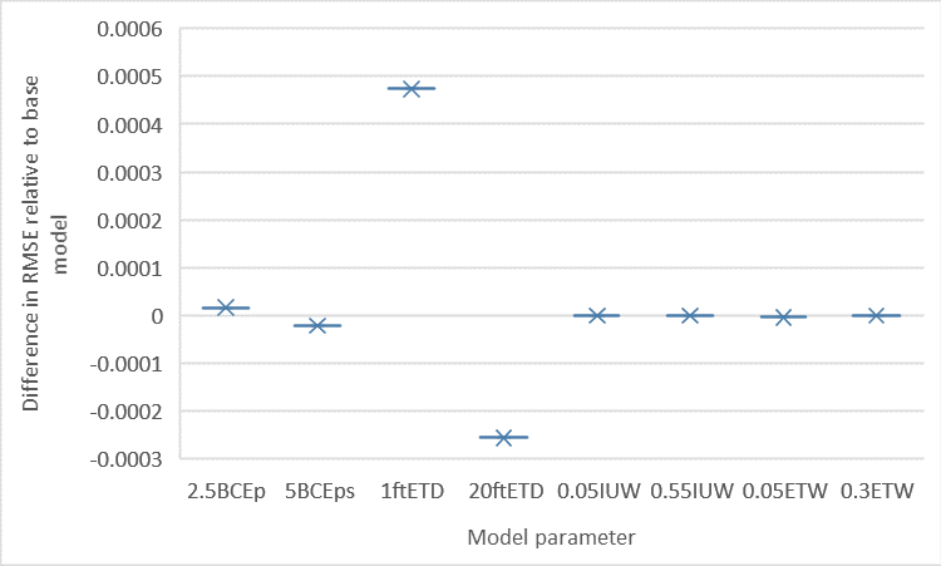

Figure 30: Sensitivity of UZF model parameters

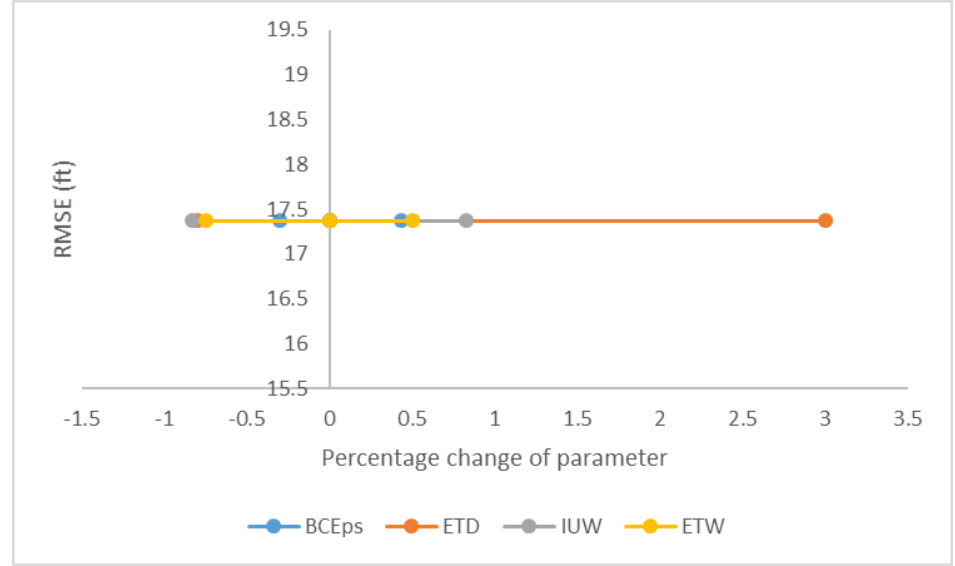

Figure 31: Sensitivity of UZF parameters with graph scaled for comparison to aquifer parameters 


\section{CONCLUSION AND RECOMMENDATIONS}

\subsection{Conclusion}

The objective of this study was to analyze the impact of precipitation on the appearance of Holgate Lake. Holgate Lake is an ephemeral lake. It is hypothesized that precipitation and changes in groundwater level cause the lake to form intermittently. The study area was a 6 square mile domain in southeast Portland. Kelly Butte and Powell Butte delineated the northeastern and western boundaries of the model. Johnson Creek delineated the southwestern boundary of the model. The study included analysis of hydrologic conditions over a 318-day period from June $14^{\text {th }}, 1999$ to April $26^{\text {th }}, 2000$. This period coincided with data collected by USGS and City of Portland from well 01S/02E-14BAD, a test well located in the lakebed of Holgate Lake. The observed heads collected over the 318-day period were above the lake bed level for 18 of the 43 days under analysis at well 01S/02E-14BAD. The simulated heads modeled during the 318-day period were above the lakebed level for 28 of the 43 days under analysis. In months with less precipitation, the model had stronger correlation to the observed heads. However, the simulated heads were initially significantly greater than the observed heads (Figure 32). As the model run progressed, the simulated heads fell below the level of the observed heads.

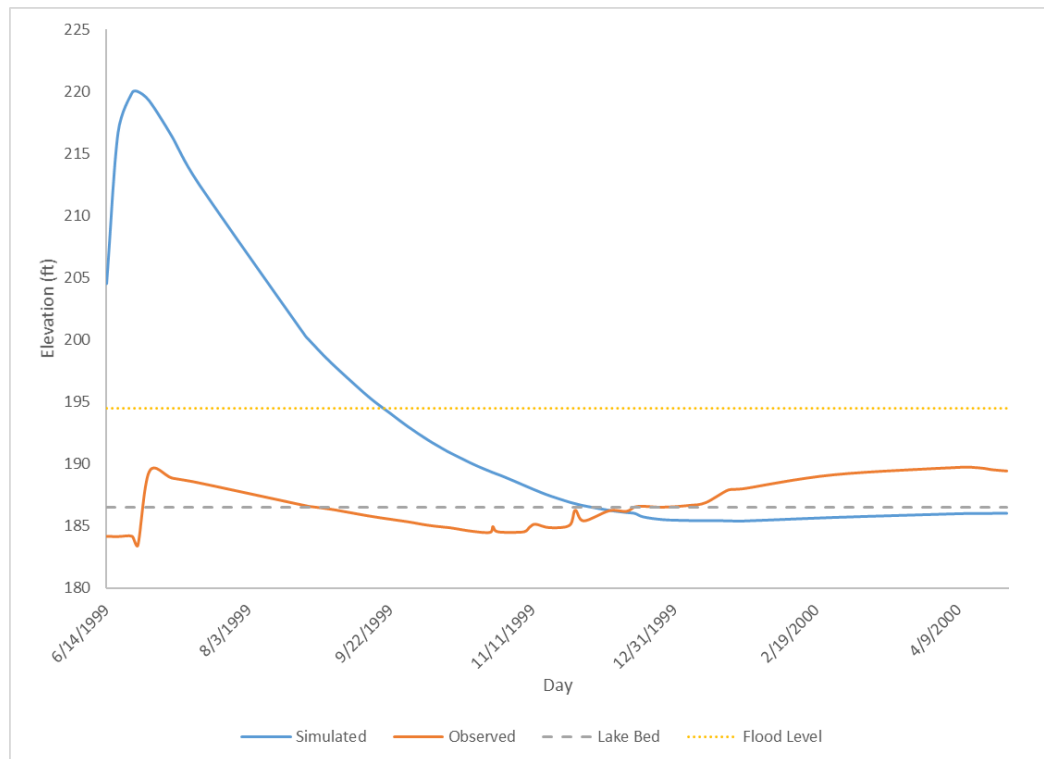

Figure 32: Observed and simulated heads at well 01S/02E-14BAD compared to lakebed and flood levels 
The model was more sensitive to aquifer parameters than hydrologic parameters. As modeled, this suggested that the appearance of Holgate Lake was more strongly influenced by hydraulic conductivity and storage capacity than infiltration and precipitation. The model exceeded flood levels during the warmer, drier months, and returned to a dry lakebed by late fall. This is opposite of the observed trend at Holgate Lake. The lake has been observed to appear in early winter each year and dry out by midsummer.

\subsection{Recommendations}

This study incorporated numerous simplifying assumptions to facilitate analysis. It is important to understand the significance of each simplifying assumption. The hydrogeology of the study area was based off of borehole data from a single well. In future analyses, it would be beneficial to consider changes in hydrogeology throughout the study area. The model showed sensitivity to changes in hydraulic conductivity and storage capacity. These parameters are impacted by hydrogeology. It is reasonable to assume that a more complex rendering of the study area hydrogeology would impact model results.

The boundary conditions used in the model were no-flow boundary conditions at the model domain borders and a head-dependent flux boundary. The no-flow boundary condition inhibits the natural groundwater gradient. In future studies, it would be beneficial to expand the study area in order to include physical boundary conditions such as the Willamette River and the Portland Hills. Physical and hydraulic features could be extracted from a regional scale model and used as boundary conditions at the local scale. The influence of Johnson Creek was assumed to be constant throughout the duration of the model. In future studies, it would be beneficial to include seasonal fluctuations in conductance for Johnson Creek.

The model should be properly calibrated. The model did not include a steady-state calibration period. In future studies, the model should be calibrated under steady-state conditions. After calibration under steady-state, the model should be run under transient conditions and re-calibrated. The inconsistencies between observed and simulated heads indicate calibration error. Observed heads from a single day were used in an effort to 
calibrate the model. Additional data over a longer temporal and spatial domain should be employed in future studies to improve model performance.

The model assumed that precipitation could be captured by infiltration inputs using the Hargreaves Method. In future studies, it would be beneficial to use a surface water model to capture precipitation inputs. The surface water model could then be coupled with the groundwater-flow model to better capture surface -subsurface interactions.

Once the model is calibrated and the impact of simplifying assumptions is better understood, the model could be used to assess flood risks in the Holgate Lake area. The model could be run under climate change scenarios. The results of the model could be used to support various groundwater management scenarios and development of local infrastructure. The simplified model used in this analysis lacks sufficient detail to accurately characterize changes in flood risk. 


\section{REFERENCES}

(2005). "Johnson Creek Watershed Characterization." Bureau of Environmentsl Services:

City of Portland https://www.portlandoregon.gov/bes/article/214368

U.S. Geological Survey, The National Map (2017) 3DEP products and services: The National Map, 3D Elevation Program Web page, accessed at https://nationalmap.gov/3DEP/3dep_prodserv.html

Anderson, M. P., Woessner, W. W., and Hunt, R. J. (2015). Applied Groundwater Modeling: Simulation of Flow and Advective Transport (2nd ed.). Academic Press.

Brooks, R., and Corey, A. (1964). "Hydraulic Properties of Porous Media." Colorado State University. Retrieved from https://dspace.library.colostate.edu/bitstream/handle/ 10217/61288/HydrologyPapers_n3.pdf?sequence

Conlon, T. D., Wozniak, K. C., Woodcock, D., Herrera, N. B., Fisher, B. J., Morgan, D. S., Lee, K. K., and Hinkle, S. R. (2005). Ground-Water Hydrology of the Willamette Basin, Oregon: U.S. Geological Survey Scientific Investigations Report 2005-5168, 83 p. https://pubs.usgs.gov/sir/2005/5168/

Ely, D. M., and Kahle, S. C. (2012). Simulation of Groundwater and Surface-Water Resources and Evaluation of Water-Management Alternatives for the Chamokane Creek Basin, Stevens County, Washington: U.S. Geological Survey Scientific Investigations Report 2012-5224, 74 p. https://pubs.usgs.gov/sir/2012/5224/pdf/sir20125224.pdf

Farg, E., Arafat, S. M., Abd El-Wahed, M. S., and El-Gindy, A. M. (2012). "Estimation of Evapotranspiration ETc and Crop Coefficient Kc of Wheat, in south Nile Delta of Egypt Using integrated FAO-56 approach and remote sensing data." The Egyptian Journal of Remote Sensing and Space Sciences, 15, 83-89.

Feinstein, D., Fienen, M., Kennedy, J., Buchwald, C., and Greenwood, M. (2012). Development and Application of a Groundwater/Surface-Water Flow Model using MODFLOW-NWT for the Upper Fox Basin, southeastern Wisconsin: U.S. Geological Survey Scientific Investigations Report 2012-5108, 124 p. https://pubs.usgs.gov/sir/2012/5108/pdf/sir2012-5108_web.pdf 
Franke, O. L., Reilly, T. E., and Bennett, G. D. (1987). "Definition of Boundary and Initial Conditions in the Analysis of Saturated Ground-water flow Systems: An introduction." In Applications of Hydraulics. Washington, D.C.: U.S. Geological Survey. Gresham Outlook. (1949, March 3). "Gilbert home covered by temporary lake." Gresham Outlook, photograph and caption, p. 1.

Gresham Outlook (1969, February 6), "S.E. Long Street Residents Seeking Help from County." Gresham Outlook, p. 3.

Hargreaves, G. H., and Allen, R. G. (2003). "History and Evaluation of Hargreaves Evapotranspiration Equation." Journal of Irrigation and Drainage Engineering, 129(1), 53-63.

Johnson, A. (1967). Specific Yield - Compilation of Specific Yields for Various Materials. U.S. Geological Survey Water Supply Paper 1662-D, 80 p. https://pubs.usgs.gov/wsp/1662d/report.pdf

Lee, K. K., and Snyder, D. T. (2009). Hydrology of Johnson Creek Basin, Oregon: U.S. Geological Survey Scientific Investigations Report 2009-5123, 56 p. https://pubs.usgs.gov/sir/2009/5123/pdf/sir20095123.pdf

Morgan, D. S., and McFarland, W. D. (1996). Simulation analysis of the ground-water flow system in the Portland Basin, Oregon and Washington: U.S. Geological Survey WaterSupply Paper 2470-B, 78 p. https://pubs.er.usgs.gov/publication/wsp2470B

Niswonger, R. G., Panday, S., and Ibaraki, M. (2011). MODFLOW-NWT, A Newtonian Formulation for MODFLOW-2005. U.S. Geological Survey Techniques and Methods 6-A37, 44 p. https://pubs.usgs.gov/tm/tm6a37/pdf/tm6a37.pdf

Niswonger, R. G., Prudic, D. E., and Regan, R. S. (2006). Documentation of the UnsaturatedZone Flow (UZF1) Package for modeling unsaturated flow between the land surface and the water table with MODFLOW-2005: U.S. Geological Survey Techniques and Methods 6-A19, 62 p. https://pubs.usgs.gov/tm/2006/tm6a19/pdf/tm6a19.pdf NWIS Site Information for Oregon: Site Inventory. (n.d.). Retrieved from https://nwis.waterdata.usgs.gov/or/nwis/inventory? Rothacher, J. (1963). "Net Precipitation under a Douglas-Fir Forest." Forest Science, 9(4), 423-429. 
Snyder, D. T. (2008). Estimated Depth to Ground Water and Configuration of the Water Table in the Portland, Oregon Area: U.S. Geological Survey Scoentific Investigations Report 2008-5059, 52 p. https://pubs.usgs.gov/sir/2008/5059/index.html

Snyder, D. T., and Haynes, J. V. (2010). Groundwater conditions during 2009 and changes in groundwater levels from 1984 to 2009, Columbia Plateau Regional Aquifer System, Washington, Oregon, and Idaho: U.S. Geological Survey Scientific Investigations Report 2010-5040, 12 p. https://pubs.usgs.gov/sir/2010/5040/pdf/sir20105040.pdf

Snyder, D. T., Wilkinson, J. M., and Orzol, L. L. (1996). Use of a ground-water flow model with particle tracking to evaluate ground-water vulnerability, Clark County, Washington: U.S. Geological Survey Open-File Report 96-328, 71 p. https://pubs.usgs.gov/of/1996/0328/report.pdf

Snyder, D., Morgan, D., and McGrath, T. (1994). Estimation of ground-water recharge from precipitation, runoff into drywells, and on-site waste-disposal systems in the Portland Basin, Oregon and Washington: U.S. Geological Survey Water-Resources Investigations Report 92-4010, 34 p. https://pubs.er.usgs.gov/publication/wri924010

Swanson, R. D., McFarland, W. D., Gonthier, J. B., and Wilkinson, J. M. (1993). A description of hydrogeologic units in the Portland Basin, Oregon and Washington: U.S. Geological Survey Water-Resources Investigations Report 90-4196, 56 p. https://pubs.er.usgs.gov/publication/wri904196

Trimble, D. (1963). "Geology of Portland, Oregon and adjacent areas." (U. G. Survey, Ed.) Retrieved from National Geologic Map Database: https://ngmdb.usgs.gov/Prodesc/proddesc_23518.htm

USGS StreamStats. (n.d.). Retrieved from https://streamstats.usgs.gov/ss/ Vaughan, C. C. (n.d.). Willamette Stone and Willamette Meridian. Retrieved from The Oregon Encyclopedia: https://oregonencyclopedia.org/articles/willamette_stone_ and_willamette_meridian/\#.Wx8bfIpKjct

Williams, J. S., Lee, K. K., and Snyder, D. T. (2010). Hydrology of Johnson Creek Basin, a Mixed-Use Drainage Basin in the Portland, Oregon, Metropolitan Area: U.S. 
Geological Survey Fact Sheet 2010-3030, 2 p.

https://pubs.usgs.gov/fs/2010/3030/pdf/fs20103030.pdf

Woodward, D. G., Gannett, M. W., and Vaccaro, J. J. (1998). Hydrogeologic Framework of the Willamette Lowland Aquifer System, Oregon and Washington: U.S. Geological Survey Professional Paper 1424-B, 92 p. https://pubs.usgs.gov/pp/1424b/report.pdf 